\title{
Cost-Benefit Analysis and Relative Position
}

\section{Citation}

Cass R. Sunstein \& Robert H. Frank, Cost-Benefit Analysis and Relative Position (John M. Olin Program in Law \& Economics Working Paper No. 102, 2000).

\section{Published Version}

http://chicagounbound.uchicago.edu/law_and_economics/139/

\section{Permanent link}

http://nrs.harvard.edu/urn-3:HUL.InstRepos:12876724

\section{Terms of Use}

This article was downloaded from Harvard University's DASH repository, and is made available under the terms and conditions applicable to Other Posted Material, as set forth at http:// nrs.harvard.edu/urn-3:HUL.InstRepos:dash.current.terms-of-use\#LAA

\section{Share Your Story}

The Harvard community has made this article openly available.

Please share how this access benefits you. Submit a story.

Accessibility 


\section{University of Chicago Law School Chicago Unbound}

Coase-Sandor Working Paper Series in Law and

Economics

Coase-Sandor Institute for Law and Economics

2000

\section{Cost-Benefit Analysis and Relative Position}

Cass R. Sunstein

Robert H. Frank

Follow this and additional works at: http://chicagounbound.uchicago.edu/law_and_economics Part of the Law Commons

\section{Recommended Citation}

Cass R. Sunstein \& Robert H. Frank, "Cost-Benefit Analysis and Relative Position" (John M. Olin Program in Law and Economics Working Paper No. 102, 2000).

This Working Paper is brought to you for free and open access by the Coase-Sandor Institute for Law and Economics at Chicago Unbound. It has been accepted for inclusion in Coase-Sandor Working Paper Series in Law and Economics by an authorized administrator of Chicago Unbound. For more information, please contact unbound@law.uchicago.edu. 


\section{HICAG 0}

JOHN M. OLIN LaW \& ECONOMics W ORKINg Paper No. 102 (2D SERIES)

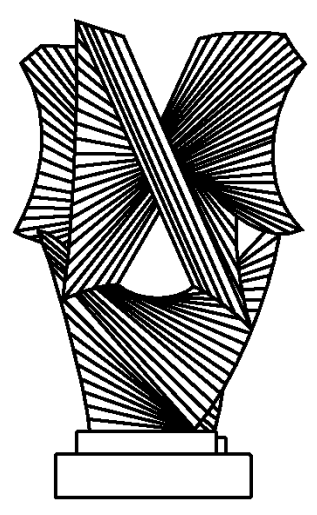

Cost-Benefit Analysis and Rel at ive Position

R obert H . F rank and Cass R. Sunstein

THE LAW SCHOOL

THE UNIVERSITY OF CHICAGO

This paper can be downloaded without charge at the

Social Science Research N etwork E lectronic Paper Collection:

http://papers.ssrn.com/paper.taf?abstract_id=XXXXXX 
Preliminary draft $7 / 27 / 00$

All rights reserved

\title{
Cost-Benefit Analysis and Relative Position
}

\author{
Robert H. Frank ${ }^{*}$ and Cass R. Sunstein ${ }^{* *}$
}

The movement for cost-benefit analysis of regulatory problems has proved stunningly successful. By Executive Order, Presidents Reagan, Bush, and Clinton have all required cost-benefit analysis of major regulations. ${ }^{1}$ Partly as a result, agencies routinely attempt to calculate the costs and benefits of their activities. ${ }^{2}$ Congress has also shown considerable interest in cost-benefit analysis, requiring both OMB and EPA to produce monetized accounts of the consequences of regulation. ${ }^{3}$ Courts themselves have been highly receptive to efforts to mandate cost-benefit analysis, ${ }^{4}$ asking agencies to monetize costs, benefits, or both. ${ }^{5}$ In a recent decision, the court of appeals for the D.C. Circuit -- the most important court in federal regulatory law -- has made clear that Congress will have to speak unambiguously if it intends to forbid consideration of cost. ${ }^{6}$ In sum, both the executive and the judiciary have converged on a kind of default rule in favor of cost-benefit analysis, to be used unless Congress expressly precludes it.

We believe that the movement toward cost-benefit analysis of regulatory initiatives is generally desirable and that most of the conventional criticisms of it are unconvincing. ${ }^{7}$ But those who approve of cost-benefit analysis need practical ways to measure both costs and benefits, and it is here that many questions remain, for theory and practice alike. Our focus is on the standard economic approach, which attempts to estimate people's willingness to pay for the various goods at issue. ${ }^{8}$ We intend to criticize this approach on the ground that it ignores a central point about valuation, thus producing numbers that systematically undervalue the benefits of regulation.

\footnotetext{
* Goldwin Smith Professor of Economics, Ethics, and Public Policy, Cornell University.

** Karl N. Llewellyn Distinguished Service Professor, University of Chicago, Law School and Department of Political Science. We are grateful to Christine Jolls, Eric Posner, and Richard Posner for very helpful comments on a previous draft. An earlier version of this paper was Working Paper 00-05 (June 2000) from the AEI-Brookings Joint Center for Regulatory Studies, and we are very grateful to Robert Hahn and others at the Joint Center for encouragement and assistance.

${ }^{1}$ See Executive Order 12291, 46 Fed. Reg. 13193 (1980); Executive Order 12866, 3 CFR 638, 649 (1993)

${ }^{2}$ See, e.g., Economic Analyses at EPA: Assessing Regulatory Impact (Richard Morgenstern ed. 1997); Thomas McGarrity, Reinventing Rationality (1994).

${ }^{3} 5$ USC 1532

${ }^{4}$ See, e.g., Corrosion Proof Fittings v. EPA, 947 F.2d 1201 (9 $9^{\text {th }}$ Cir. 1991); Grand Canyon Air Tour Coalition . FAA, 154 F.3d 455, 475 (DC Cir 1998); NRDC v. EPA, 937 F.2d 641, 643-46 (DC Cir 1991); Michigan v. EPA, 2000 US App LEXIS 3209 (DC Cir., March 3, 2000).

${ }^{5}$ See cases cited in note 4 supra.

${ }^{6}$ Michigan v. EPA, 2000 US App LEXIS 3209 (DC Cir, March 3, 2000).

${ }^{7}$ See Robert H. Frank, J. Legal Stud. (forthcoming 2000); Cass R. Sunstein, Cognition and Cost-Benefit Analysis, J. Legal Stud. (forthcoming 2000); Cass R. Sunstein, Free Markets and Social Justice ch. 10 (1997).

${ }^{8}$ See, e.g., W. Kip Viscusi, Fatal Tradeoffs (1992).
} 
Policy analysts rely for the most part on two methods for estimating willingness to pay. One is the hedonic pricing method, which attempts to infer valuations from observable market behavior. For example, analysts might estimate the value of safety by examining how wages vary with workplace injury levels. ${ }^{9}$ In the contingent valuation approach, generally used when market evidence is unavailable, analysts ask how much people would be willing to pay to reduce or avoid a wide range of dangers -- specific health problems associated with ozone or particulate matter; various kinds of workplacerelated mortality risks; risks associated with air travel; risks of injury or death in automobile accidents; and so on. ${ }^{10}$ Relying primarily on hedonic pricing studies, but also on contingent valuation studies, federal agencies have used estimates of the value of a statistical life saved that range from $\$ 1.5$ million (used by the FAA) to $\$ 5.8$ million (used at least once, but not consistently, by the EPA). ${ }^{11}$

Monetization, as measured by estimates of willingness to pay, is not limited to mortality risks. For example, the EPA recently provided a wide range of numbers for health problems short of mortality. ${ }^{12}$ It considers a risk of congestive heart failure to be worth $\$ 20,600$ for people under 65 , but $\$ 16,600$ for people over 65 . It considers an episode of acute bronchitis to be worth $\$ 45$; an emergency visit to the hospital for asthma, \$9000; chronic bronchitis, \$260,000; and a single episode of shortness of breath, $\$ 5.30$. In all cases, these numbers are generated on the basis of estimates of what affected individuals would be willing to pay to avoid negative outcomes.

For present purposes we shall simply assume that these numbers are basically sound, in the sense that they represent good estimates of private willingness to pay. We shall also assume that private willingness to pay is, in general, the appropriate basis for monetizing the benefits of regulation. ${ }^{13}$ We nonetheless suggest that the actual numbers on which federal agencies rely understate the social benefits of many regulations by a substantial amount. It follows that important policies are being defended, and made, on the basis of assessments that greatly undervalue the net benefits of regulatory interventions. Where the government currently says that the value of a statistical life is about $\$ 4$ million, it ought to be saying that the value is somewhere between $\$ 4.7$ million and $\$ 7$ million. At the very least, our analysis suggests that when government agencies are unsure how to value regulatory benefits along a reasonable range, they should make choices toward or at the upper end.

The essential reason for our claim is that people care a great deal about their relative economic position, and not solely, and often not mostly, about their absolute economic position. Current estimates tell us what an individual, acting in isolation, would be willing to pay for, say, an increase in safety on the job. But when an individual buys additional safety in isolation, he experiences not only an absolute decline in the

\footnotetext{
9 See, for example, Richard Thaler and Sherwin Rosen, The Value of Saving a Life: Evidence from the Labor Market, in Household Production and Consumption 266 (ed. N. Terleckjz 1976).

${ }^{10}$ For general discussion, see Symposium, J. Econ. Persp. (Fall 1994).

${ }^{11}$ See Mathew Adler and Eric Posner, Cost-Benefit Analysis When Preferences Are Distorted, J Legal Stud. (forthcoming 2000).

12 See U.S. EPA Innovative Strategies \& Economics Group, Office of Air Quality Planning \& Standards, Regulatory Impact Analyses for the Particulate Matter and Ozone National Ambient Air Quality Standards and Proposed Regional Haze Rule 12-43 (1997).

${ }^{13}$ This is an assumption and no more. It is criticized in Sunstein, supra note, and defended in Frank, supra note.
} 
amounts of other goods and services he can buy, but also a decline in his relative living standards. In contrast, when a regulation requires all workers to purchase additional safety, each worker gives up the same amount of other goods, so no worker experiences a decline in relative living standards. If relative living standards matter, then an individual will value an across-the-board increase in safety more highly than an increase in safety that he alone purchases.

The "willingness to pay" numbers used in the standard estimates take no account of this difference; they are based on an implicit assumption that individuals care only about absolute living standards, not at all about relative living standards. This assumption is wrong. If people could maintain their relative economic position, they would be willing to pay more, and possibly a great deal more, to purchase many of the goods that regulation attempts to deliver. A central assumption here, which we defend in some detail, is that income is in large part a positional good, valued in terms of relative position, whereas many regulatory benefits, such as health care, safety, parental leave, and leisure time, are largely or primarily nonpositional goods, valued for their own sake and more independently of what others have. Our minimal claim, then, is that existing numbers are too low insofar as they fail to take account of concerns about relative economic position, and that a serious conceptual defect is thus inherent in current approaches, one that merits much further investigation. Our more ambitious claim is that in order to be accurate, the existing numbers should be increased substantially, and we attempt to show how the more accurate numbers might be generated. We hope that those who object to that particular attempt will be motivated not to defend the implausible view that absolute position is all that matters, but to develop more accurate ways to incorporate positional concerns into cost-benefit analysis.

The arguments we make here go well beyond the particular area of cost-benefit analysis. In many contexts, consumers find themselves on a positional treadmill, in which their choices do not really make them happier or better off, but instead serve largely to keep them in the same spot in the hierarchy. ${ }^{14}$ Many actual and imaginable laws can stop or slow down the positional treadmill, thus maintaining people's relative position while also giving them something of value. People care about maintaining relative position not only because of envy, status-seeking, or reputational concerns; a particularly important point is that the frame of reference for evaluating many goods and services is set socially rather than individually, and inevitably so. ${ }^{15}$ For many goods and services, the holdings and actions of other provide the frame of reference against which each person evaluates his holdings and actions. When the frame of reference changes, evaluations will change as well. Improvements in the frame of reference often mean that people experience previously satisfactory goods and services as undesirable, a kind of prisoner's dilemma that may be best solved through law. We will discuss a number of examples here. While our focus is on cost-benefit analysis, an especially salient current topic, our discussion bears on many other problems as well.

This essay comes in several parts. Part I traces the rise of cost-benefit analysis within the national government, gives a sense of the numbers that government institutions are now using, and briefly explains how those numbers have been chosen. Part II

\footnotetext{
${ }^{14}$ See Robert H. Frank, The Demand for Unobservable and Other Nonpositional Goods, 75 American Economic Review 101 (1985).

${ }^{15}$ See Robert H. Frank, The Frame of Reference As A Public Good, 107 Economic Journal 1832 (1996).
} 
discusses the central importance of relative economic position to people's perceptions of their own well-being. Part III explores how some of the key benefit calculations would be altered by an understanding of the importance of relative position. Part IV discusses several theoretical issues, focusing on the objection that positional concerns should play no role in public policy. Part V explores some limits and extensions of our argument. We consider the implications of the fact that many regulatory programs benefit not all people but subclasses, and we discuss how positional concerns help justify nonwaivable contractual terms in employment law. Part VI is a brief conclusion.

\section{The Growth of Cost-Benefit Analysis}

In this section, we outline the rise of cost-benefit analysis, as produced by the executive, judicial, and legislative branches of the national government. The general lesson is that we are fast approaching the end of a "first generation" debate, between advocates and critics of cost-benefit analysis, with general victory for the advocates. ${ }^{16}$ At the same time, we have only started to enter into the equally important "second generation" debate, over the appropriate method for valuing costs and benefits. Hence neither Congress nor courts have given even minimal guidance for valuing regulatory benefits, and there is a great deal of unexplained disparity even within the practices of those agencies firmly committed to cost-benefit principles.

\section{A. Executive Branch: A Presidential "Supermandate," But Without Specifying Values}

During the last twenty years, cost-benefit analysis has become a prominent practice within the executive branch of the national government. Though economic advisers have attempted to ensure cost-benefit review since the Nixon Administration, ${ }^{17}$ the cost-benefit principle did not receive prominent recognition until Executive Order $12291,{ }^{18}$ issued by President Reagan in 1981. The purpose of this executive order was to ensure that all major rules would be subject to cost-benefit analysis and that such analysis would be the "basis" of decision, at least to the extent permitted by law. ${ }^{19}$ At the same time, the Office of Management and Budget (OMB) was entrusted with the power to oversee agency cost-benefit analyses to ensure their basic rationality and sense. ${ }^{20}$ The movement in the direction of cost-benefit analysis was much accelerated in 1985 with the issuance of Executive Order $12498,{ }^{21}$ requiring that cost-benefit analysis provide the basis for an "annual regulatory plan" to be issued by all executive agencies. It was

\footnotetext{
${ }^{16}$ By this we mean both a political victory and an intellectual victory. One of us has criticized some defenses of cost-benefit analysis on the ground that they wrongly assume the "commensurability" of all social goods, see Cass R. Sunstein, Incommensurability and Valuation in Law, 92 Mich L Rev 779, 842 (1994). But this criticism is not meant as an objection to the comparison of costs and benefits as a policy tool, designed to discipline inquiry. See id. at 842 . We are concerned here with cost-benefit analysis as a policy tool, and for that purpose it is not necessary to engage other, more abstract debates on the nature of human valuation..

${ }^{17}$ See Richard Pildes and Cass R. Sunstein, Reinventing the Regulatory State, 62 U Chi L Rev 1, 13-14 (1995).

${ }^{18} 3$ CFR 128 (1981).

${ }^{19} \mathrm{Id}$

${ }^{20} \mathrm{Id}$

${ }^{21} 3$ CFR 323 (1985).
} 
pursuant to this executive order that annual volumes, often containing OMB instructions for the valuation of risks, became a prominent basis for understanding federal regulatory activity. ${ }^{22}$

Many people doubted whether President Clinton would endorse the idea that regulatory judgments should be made with close reference to cost-benefit balancing. Despite the misgivings of some environmental organizations, President Clinton's Executive Order $12866,{ }^{23}$ issued in 1993, firmly embraced cost-benefit analysis as a central ingredient in regulatory decisions. The Order does shift, in certain ways, from the Reagan-Bush initiatives, principally via references to "equity" and "distributive impacts" as relevant factors in agency analysis. ${ }^{24}$ But these are modest changes in a presidential requirement that continues to require cost-benefit analysis of major rules. Thus the executive branch has endorsed cost-benefit balancing for over twenty years, and it seems reasonable to suggest that insofar as the White House is overseeing the federal regulatory process, cost-benefit analysis will continue to play a central organizing role, no matter the party affiliation of the president.

Notwithstanding this point, a key limitation in the current process within the executive branch is the absence of an agreed-upon system for assessing the relevant values. ${ }^{25}$ As we shall soon see, agency practices are widely divergent. OMB has attempted to discipline agency inquiry, but only through unenforced and somewhat vague guidance and occasional intervention, ${ }^{26}$ and without much of an underlying theory aside from general reliance on private "willingness to pay."

\section{B. Courts: A Cost-Benefit Default Principle}

The executive branch has not acted alone. In one of the most noteworthy developments in the last twenty years of administrative law, courts have also enforced a form of cost-benefit balancing, at least where Congress has not barred them from doing so. ${ }^{27}$ Indeed, the most dramatic innovation, noted above, is a new doctrine permitting and possibly even requiring cost-benefit analysis unless Congress has expressly directed otherwise. ${ }^{28}$ Federal law now reflects a kind of default principle: Agencies will consider costs, and thus undertake cost-benefit analysis, if Congress has not unambiguously said that they cannot.

Thus judges have invalidated regulatory action that imposes high costs without significant benefits. ${ }^{29}$ They have also policed agency action to ensure at least a rough kind

\footnotetext{
${ }^{22}$ See, e.g., Office of Management and Budget, Regulatory Program of the United States Government, 1985-1986; for OMB's most recent statement, see OMB, Guidance to Regulatory Agencies (on file with the authors). Like all other governmental bodies, OMB ignores positional considerations in its effort to state "best practices" for cost-benefit analysis.

${ }^{23} 3$ CFR 638 (1993).

${ }^{24} \mathrm{Id}$.

${ }^{25}$ For a complaint in this vein, see Robert W Hahn, Assessing the Quality of Regulatory Impact Analyses (unpublished manuscript 2000). See OMB, supra note, for effort to codify "best practices"; but OMB's guidance is merely that, and hence has no binding quality.

26 See Thomas O. McGarrity, Reinventing Rationality: The role of regulatory analysis in the federal bureaucracy (Cambridge 1991).

${ }^{27}$ See note supra; Corrosion Proof Fittings v. EPA, 947 F.2d 1201 (9th Cir. 1991).

${ }^{28}$ Michigan v. EPA, 2000 US App LEXIS 3209 (DC Cir, March 3, 2000).

${ }^{29}$ Corrosion Proof Fittings v. EPA, 947 F.2d 1201 (9th Cir. 1991); AFL-CIO v. OSHA, 965 F.2d 962 (11th Cir. 1992). American Petroleum Institute, 448 US; is in the same general spirit. There the plurality held
} 
of proportionality between costs and benefits. ${ }^{30}$ Sometimes courts have been quite aggressive in requiring proportionality as part of their function in reviewing agency action to test whether it is "arbitrary, capricious, or an abuse of discretion. ${ }^{31}$ Courts have insisted that some amounts of money are too much to spend for small benefits. ${ }^{32}$ On the other hand, they have failed to give much guidance for deciding, in general, when a great deal is too much. Here, as within the executive branch, the appropriate valuation of regulatory benefits has received exceedingly little attention.

\section{Congress and the Failed Supermandate}

Executive and judicial developments do not mean that the regulatory state is now routinely subject to scrutiny for conformity with cost-benefit criteria. ${ }^{33}$ Presidents and courts have circumscribed authority; they must act consistently with federal statutes, which often forbid cost-benefit balancing. Consider, for example, the Clear Air Act ${ }^{34}$, the Clean Water $\mathrm{Act}^{35}$, the Occupational Safety and Health $\mathrm{Act}^{36}$, the Delaney Clause ${ }^{37}$, and the Safe Water Drinking Act ${ }^{38}$, many of whose provisions ban agencies from balancing costs against benefits. It is partly for this reason that the American regulatory state contains many regulations imposing high costs not justified by corresponding benefits. ${ }^{39}$

Hence much of the contemporary interest in regulatory reform has been directed toward Congress. Consider the fact that in the mid-1990s, repeated efforts were made to impose a "supermandate" that would require all agencies to undertake cost-benefit analysis and to make decisions on the basis of that analysis. ${ }^{40}$ Notably, these proposals included no guidance for the valuation of life and other benefits from regulation. Partly because of irreconcilable legislative differences over the question of valuation, the proposed supermandate was defeated. But the national legislature has not uniformly rejected cost-benefit balancing. In the area of health and environmental protection, two important statutes, involving toxic substances and pesticides, contemplate a form of costbenefit analysis. $^{41}$ More recently and more globally, the Unfunded Mandates Act contains two relevant provisions, imposed on all regulatory activity. ${ }^{42}$ First, significant regulatory actions must be accompanied by a statement that includes "a qualititative and

that OSHA must show a "significant risk" before regulating a toxic substance. The Court subsequently held that OSHA need not engage in cost-benefit analysis. But in asserting the need for a demonstration of a significant risk, the plurality emphasized that an alternative view would allow "the imposition of significant cost for little, if any, discernible gain.” Id. at XX

${ }^{30}$ See note supra.

${ }^{31} 5$ USC 706.

${ }^{32}$ See note supra.

${ }^{33}$ Thomas McGarrity, supra note.

${ }^{34} 42$ USC $\$ 7401$ et seq (1989).

3533 USC $\$ 1251$ et. seq (1994).

${ }^{36} 29$ USC $\$ 651$ et seq. (1994).

${ }^{37} 21$ USC $\$ \S 348$ (c)(3)(1), 360b(d)(1)(I), 379e(b)(5)(B).

${ }^{38} 42$ USC $\$ \$ 300 j-8(d)(1988)$.

${ }^{39}$ See Robert Hahn, Risks, Costs, and Lived Saved (1996); W. Kip Viscusi, Fatal Tradeoffs (1993).

${ }^{40}$ See Cass R. Sunstein, Congress, Constitutional Moments, and the Cost-Benefit State, 48 Stan. L. Rev. 247 (1996).

${ }^{41}$ See Toxic Substances Control Act (15 USC 2601 et seq); Federal Insecticide, Fungicide, and Rodenticide Act (FIFRA) (7 U.S.C.A. $\S \S 136$ et seq.).

${ }^{42} 5$ USC 1532 
quantitative assessment of the anticipated costs and benefits of the Federal mandate." ${ }^{43}$ Second, all agencies must "identify and consider a reasonable number of regulatory alternatives and from those alternatives select the least costly, most cost-effective, or least burdensome alternative that achieves the objectives of the rule." ${ }^{14}$ These provisions enshrine a form of cost-benefit analysis for major rules; but in keeping with the pattern that we have seen thus far, they are silent on how agencies are supposed to value the goods at stake.

\section{Practice}

What have agencies actually done when they have done cost-benefit analysis? It is clear that the general practice is to build on some version of the contingent valuation and hedonic pricing methods discussed above. Thus agencies attempt to measure people's willingness to pay, using actual choices if possible, and contingent valuation if necessary. It is on the basis of this sort of analysis that the EPA recently compiled the following table ${ }^{45}$ :

\section{Table 1 Willingness-to-Pay Estimates (Mean Values)}

\begin{tabular}{|l|c|}
\hline \multicolumn{1}{|c|}{ Health Endpoint } & $\begin{array}{c}\text { Mean WTP Value per Incident } \\
(\mathbf{1 9 9 0} \$)\end{array}$ \\
\hline $\begin{array}{l}\text { Mortality } \\
\text { Life saved } \\
\text { Life year extended }\end{array}$ & $\$ 4.8$ million \\
$\$ 120,000$
\end{tabular}

\footnotetext{
${ }^{43} 2$ USC 202(a)(2).

${ }^{44} 2$ USC 202 (a)(3)-(4). Of course a cost-effectiveness principle should not be identified with a cost-benefit requirement. The idea that agencies should seek the lowest cost way of achieving a goal is narrower and less controversial than the idea that agencies should compare costs with benefits.

${ }^{45}$ Innovative Strategies Group, Environmental Protection Agency, Regulatory Impact Analysis, Ozone and Particulates (1998).
} 
But there is also a great deal of variation both within and across agencies. With respect to statistical lives, consider the following table ${ }^{46}$ :

Table 2: Valuations of Life

\begin{tabular}{|c|c|c|c|}
\hline AGENCY & REGULATION & CITATION & $\begin{array}{l}\text { VALUE } \\
(\$ M)\end{array}$ \\
\hline $\begin{array}{l}\text { Department of Transportation - } \\
\text { Federal Aviation Administration }\end{array}$ & $\begin{array}{l}\text { Proposed Establishment of the } \\
\text { Harlingen Airport Radar } \\
\text { Service Area, TX }\end{array}$ & $\begin{array}{l}55 \text { FR } 32064 \\
\text { August } 6,1990\end{array}$ & 1.5 \\
\hline $\begin{array}{l}\text { Department of Agriculture - } \\
\text { Food Safety and Inspection Service }\end{array}$ & $\begin{array}{l}\text { Pathogen Reduction: Hazard } \\
\text { Analysis and Critical Control } \\
\text { Point Systems }\end{array}$ & $\begin{array}{l}61 \text { FR } 38806 \\
\text { July } 25,1996\end{array}$ & 1.6 \\
\hline $\begin{array}{l}\text { Department of Health and } \\
\text { Human Services - Food and Drug } \\
\text { Administration }\end{array}$ & $\begin{array}{l}\text { Regulations Restricting the Sale } \\
\text { and Distribution of Cigarettes } \\
\text { and Smokeless Tobacco to } \\
\text { Protect Children and } \\
\text { Adolescents }\end{array}$ & $\begin{array}{l}61 \text { FR } 44396 \\
\text { August 28, } 1996\end{array}$ & 2.5 \\
\hline $\begin{array}{l}\text { Department of Transportation - } \\
\text { Federal Aviation Administration }\end{array}$ & $\begin{array}{l}\text { Aircraft Flight Simulator Use in } \\
\text { Pilot Training, Testing, and } \\
\text { Checking and at Training } \\
\text { Centers }\end{array}$ & $\begin{array}{l}\text { 61 FR } 34508 \\
\text { July 2, } 1996\end{array}$ & 2.7 \\
\hline $\begin{array}{l}\text { Environmental Protection } \\
\text { Agency }\end{array}$ & $\begin{array}{l}\text { Protection of Stratospheric } \\
\text { Ozone }\end{array}$ & $\begin{array}{l}53 \text { FR } 30566 \\
\text { August } 12,1988\end{array}$ & 3 \\
\hline $\begin{array}{l}\text { Department of Health and } \\
\text { Human Services - Food and Drug } \\
\text { Administration }\end{array}$ & $\begin{array}{l}\text { Proposed Rules to Amend the } \\
\text { Food Labeling Regulations }\end{array}$ & $\begin{array}{l}56 \text { FR } 60856 \\
\text { November 27, } \\
1991\end{array}$ & 3 \\
\hline $\begin{array}{l}\text { Department of Transportation - } \\
\text { Federal Aviation Administration }\end{array}$ & $\begin{array}{l}\text { Financial Responsibility } \\
\text { Requirements for Licensed } \\
\text { Launch Activities }\end{array}$ & $\begin{array}{l}61 \text { FR } 38992 \\
\text { July } 25,1996\end{array}$ & 3 \\
\hline $\begin{array}{l}\text { Department of Agriculture - } \\
\text { Food and Nutrition Service }\end{array}$ & $\begin{array}{l}\text { Proposed National School } \\
\text { Lunch Program and School } \\
\text { Breakfast Program }\end{array}$ & $\begin{array}{l}59 \text { FR } 30218 \\
\text { June } 10,1994\end{array}$ & $1.5,3.0$ \\
\hline $\begin{array}{l}\text { Environmental Protection } \\
\text { Agency }\end{array}$ & $\begin{array}{l}\text { National Ambient Air Quality } \\
\text { Standards for Particulate Matter }\end{array}$ & $\begin{array}{l}62 \text { FR } 38652 \\
\text { July } 18,1997\end{array}$ & 4.8 \\
\hline $\begin{array}{l}\text { Environmental Protection } \\
\text { Agency }\end{array}$ & $\begin{array}{l}\text { National Ambient Air Quality } \\
\text { Standards for Ozone }\end{array}$ & $\begin{array}{l}62 \text { FR } 38856 \\
\text { July } 18,1996 \\
\end{array}$ & 4.8 \\
\hline $\begin{array}{l}\text { Department of Health and } \\
\text { Human Services - Food and Drug } \\
\text { Administration }\end{array}$ & $\begin{array}{l}\text { Medical Devices: Current Good } \\
\text { Manufacturing Practice }\end{array}$ & $\begin{array}{l}61 \text { FR } 52602 \\
\text { October 7, } 1996\end{array}$ & 5 \\
\hline $\begin{array}{l}\text { Department of Health and } \\
\text { Human Services - Public Health } \\
\text { Service, Food and Drug } \\
\text { Administration }\end{array}$ & $\begin{array}{l}\text { Quality Mammography } \\
\text { Standards }\end{array}$ & $\begin{array}{l}62 \text { FR } 55852 \\
\text { October 28, } 1997\end{array}$ & 5 \\
\hline $\begin{array}{l}\text { Environmental Protection } \\
\text { Agency }\end{array}$ & $\begin{array}{l}\text { Requirements for Lead-Based } \\
\text { Paint Activities in Target } \\
\text { Housing and Child-Occupied } \\
\text { Facilities }\end{array}$ & $\begin{array}{l}61 \text { FR } 45778 \\
\text { August 29, } 1996\end{array}$ & 5.5 \\
\hline $\begin{array}{l}\text { Environmental Protection } \\
\text { Agency }\end{array}$ & $\begin{array}{l}\text { National Primary Drinking } \\
\text { Water Regulations: } \\
\text { Disinfectants and Disinfection } \\
\text { Byproducts }\end{array}$ & $\begin{array}{l}\text { 63 FR } 69390 \\
\text { December } 16, \\
1998\end{array}$ & 5.6 \\
\hline $\begin{array}{l}\text { Environmental Protection } \\
\text { Agency }\end{array}$ & $\begin{array}{l}\text { Radon in Drinking Water } \\
\text { Health Risk Reduction and Cost } \\
\text { Analysis }\end{array}$ & $\begin{array}{l}64 \text { FR } 9560 \\
\text { February 26, } \\
1999\end{array}$ & 5.8 \\
\hline
\end{tabular}

${ }^{46}$ Borrowed from Matthew Adler and Eric Posner, Implementing Cost-Benefit Analysis When Preferences Are Distorted, J. Legal Stud. (forthcoming 2000). 
We do not intend to give a full answer to the question of which of these numbers is appropriate. But we do mean to identify a substantial problem with current practice, a problem with which agencies have yet to come to terms or even to acknowledge.

\section{The Importance of Relative Position}

We now attempt to show that relative economic position is important for people's subjective and objective well-being, and that absolute economic position is less significant than is ordinarily thought. For purposes of establishing our minimal proposition here, it is necessary only to establish that willingness-to-pay numbers undervalue safety and other benefits if they ignore concerns about relative position. (Notice that we are assuming a point that we will defend below: For many regulatory benefits, positional considerations are less important than they are for income.) We draw on a wide array of evidence in order to establish this point. Of course each piece of evidence is vulnerable to counterarguments, at least if taken on its own; and we will not be reluctant to mention some counterarguments here. But taken as a whole, the evidence strongly suggests that traditional methods of estimating willingness to pay seriously understate the social value of many regulatory benefits.

\section{A. Survey Evidence}

1. A Thought Experiment. Consider two hypothetical worlds:

World A: You earn $\$ 110,000$ per year, others earn $\$ 200,000$

World B: You earn $\$ 100,000$ per year, others earn $\$ 85,000$.

The income figures represent real purchasing power. Thus your higher income in World A would enable you to purchase a house that is 10 percent larger than the house you would be able to afford in World B, 10 percent more restaurant meals, and so on. Faced with a once-for-all choice between these two worlds, which would you choose?

The economic theory that underlies cost-benefit analysis suggests that World A is the uniquely correct choice. The question unambiguously specifies that the income figures represent real purchasing power, and hence prices would not be higher in World A than World B. Neoclassical economics rests on the assumption that people derive satisfaction primarily from the absolute quantity of goods and services they consume. On that measure, World A is better because it offers higher absolute consumption for every citizen. (For choosers who do not want higher levels of consumption, no matter; they might put the money in the bank for their children, or give it to their favorite charity.) That fact notwithstanding, however, a substantial proportion of people confronted with this choice say they would opt for World B. ${ }^{47}$

\footnotetext{
${ }^{47}$ See, for example, Sara J. Solnick and David Hemenway, Is More Always Better? A Survey on Positional Concerns, 37 Journal of Economic Behavior and Organization 373 (1998). When these authors offered subjects a choice similar to the one we posed above, 56 percent chose the world with higher relative income and lower absolute income. Similar numbers - with about half opting for higher relative income -- have emerged from several experiments, with about 200 subjects, involving law students at the University of Chicago Law School.

In a recent discussion of these experiments, Judge Posner complains, "[R]elative income is important as a signal of 'how one is doing.' If your boss is paying you a lot less than someone who does
} 
We do not claim that theirs is necessarily the better choice. But we do argue that it is a rational and coherent one, in part because of the importance of what the late economist Fred Hirsch called positional goods. ${ }^{48}$ A positional good is one whose value depends in significant part on how it compares with goods in the same class consumed by others. The ability to purchase such goods depends strongly on one's position in the relevant distribution of income. For example, one's ability to buy a fine painting or a house with a good view typically depends more on relative income than on absolute income. But such goods are not the only reason that relative income is important. Some people want to be toward the top of any relevant hierarchy; many more do not want to be at the bottom; and below we will discuss evidence that once a threshold level of affluence is reached, physical and psychological well-being are much better predicted by relative consumption levels than by absolute consumption levels. ${ }^{49}$

2. The Happiness Surveys. Perhaps the most striking evidence of the importance of relative position comes in the form of happiness surveys conducted over time in a variety of countries. These surveys ask people to report whether they are "very happy," "fairly happy," or "not happy." They find that happiness levels within a country at a given moment are strongly positively correlated with relative position in the country's income distribution. But the same studies find only weak long-term trends in average reported happiness levels, even for countries whose incomes have been growing steadily over time. The counterintutive conclusion is that substantial increases in economic growth do not produce substantial increases in subjective well-being.

In the early studies, Richard Easterlin found little relationship between increases in material living standards and subjective well-being. ${ }^{50}$ More particularly, Easterlin found three important patterns in the data. First, average satisfaction levels within a given country are stable over time, even in nations experiencing significant economic growth. Second, satisfaction levels across individuals within a given country do vary with income. Richer people are, on average, more satisfied than poorer people within the same nation. Third, average reported satisfaction levels are not well-correlated with average levels of national income. Nations with high levels of average income do not show higher average satisfactions than nations with lower levels of average income. In Easterlin's view, these patterns tend to suggest that relative income is far more important than absolute income in determining people's subjective well-being.

More recently, it has been found that at very low levels of poverty, increases in absolute income do tend to increase self-reported happiness. ${ }^{51}$ When people lack adequate

similar work, something is wrong, unless you have decided to substitute nonpecuniary for pecuniary income. Evening out all incomes would thus deprive people of a great deal of information about their status and prospects." Richard Posner, J. Legal Stud. (forthcoming 2000). The point is correct but not responsive. We agree that relative pay is an important signal, and to make this point is not to argue for evening out all incomes.

${ }^{48}$ Fred Hirsch, Social Limits to Growth (Harvard Univ. Press, 1976).

${ }^{49}$ For an extensive summary of this evidence, see R. H. Frank, Choosing the Right Pond, chapter 2 (Oxford University Press. 1985).

${ }^{50}$ See Richard Easterlin, Does Economic Growth Improve the Human Lot? in Nations and Households in Economic Growth: Essays in Honor of Moses Abramovitz, Paul David and Melvin Reder, eds., (Academic Press, 1974).

${ }^{51}$ See Ed Diener and Carol Diener, The Wealth of Nations Revisited: Income and the Quality of Life, 36 Social Indicators Research 275 (1995). 
food or shelter, they are likely to report themselves as happier as economic growth reduces those needs. It has also been found that average satisfaction levels are significantly higher in rich countries than in very poor ones. ${ }^{52}$ But the basic pattern identified by Easterlin continues to hold: average satisfaction levels are not significantly correlated over time with income.

3. Questions and puzzles. At a minimum, these findings demonstrate that relative income is more important than absolute income as a determinant of self-reported happiness levels. But several questions might be raised about their implications for our claims here.

First, what is the relationship between self-reported happiness and subjective happiness? Is anything real being measured? Self-reported happiness might seem to invite social comparisons; people might rate their happiness by asking how they compare to others, and hence substantial differences in happiness levels, between wealthy and less wealthy nations, might not be picked up by the responses even if substantial differences exist. It is thus possible that subjective happiness measures are simply void of normative significance.

Plausible in the abstract, this objection turns out to be wrong, or at best greatly overstated, for there is considerable evidence that self-reported happiness does measure something of significance. Numerous studies have found strong positive relationships between reported happiness levels and observable physiological and behavioral measures of well being. ${ }^{53}$ People who report that they are not happy, for example, are more likely to experience headaches, rapid heartbeat, digestive disorders, and related psychosomatic ailments. ${ }^{54}$ Those who rate themselves as very happy are more likely than others to be rated as happy by their friends, more likely to initiate social contacts, less likely to seek psychological counseling, and less likely to attempt suicide. ${ }^{55}$

A second question involves the relationship between subjective happiness and objective well-being. ${ }^{56}$ People with a greater capacity to purchase goods and services may not be subjectively happier, but they may be far better off. Among other things, they are likely to be healthier and to live longer lives. ${ }^{57}$ It is therefore reasonable to say that people who earn $\$ 70,000$, in a society where that is the median income, are likely to have better lives, other things being equal, than people who earn $\$ 30,000$, where that is the median income - even if people in these different societies report the same subjective happiness. The fact that people in relatively poor nations show relatively high levels of subjective happiness may simply reflect adaptation to relative deprivation. ${ }^{58}$

We agree that subjective happiness is not all that matters; it does not capture everything that a society should be aiming to promote. ${ }^{59}$ Economic growth would certainly be desirable insofar as it increases longevity and diminishes various risks to life

\footnotetext{
${ }^{52}$ See id.

${ }^{53}$ For a more detailed survey of this evidence, see Frank, chapter 2 (1985).

${ }^{54} \mathrm{Id}$

${ }^{55} \mathrm{Id}$

${ }^{56}$ See Amartya Sen, Development As Freedom (1999), for relevant discussion.

57 See the striking evidence of declining risks of death over time, described in W. Kip Viscusi, Fatal Tradeoffs 285 (1992).

${ }^{58}$ See the discussion of adaptive preferences in Jon Elster, Sour Grapes (1983).

${ }^{59}$ See Sen, supra note; Martha Nussbaum, Women and Human Development: The Capabilities Approach 111-48 (2000).
} 
and health, even if it had no effect whatever on subjective well-being. But subjective happiness is an important component of overall well-being, and a society whose members mostly report themselves as "unhappy" surely has a serious problem, just as a society whose members report themselves as "happy" is entitled to congratulate itself on this fact. If any income loss from a regulatory intervention does not itself decrease subjective happiness, and if the intervention confers substantial benefits, subjective and otherwise, it would seem likely that people are gaining rather than losing; and this is sufficient for our claims here.

A third question has to do with loss aversion. ${ }^{60}$ It is now well-established that people dislike losses more than they like corresponding gains. ${ }^{61}$ It follows that surprisingly little subjective gain may be created by increases in income, even if equivalent decreases in income would indeed create subjective losses. ${ }^{62}$ Perhaps people do not report themselves as significantly happier when income increases; but this does not show that they would not report themselves as significantly less happy when income decreases. The point matters for our claim here, since we will be suggesting that the economic losses associated with regulation do not matter a great deal to subjective wellbeing if relative position is held constant. But loss aversion does not undermine our basic claims. Even if people dislike losses from the status quo, they have considerable power to adjust to those losses, and indeed their fear that losses will produce significant subjective loss is not borne out by reality. ${ }^{63}$ If relative position is held constant, it is extremely unlikely that income losses, of the relatively small sort that we are discussing here, would produce more than transitory subjective losses, especially because the relevant measures will be producing regulatory benefits at the same time.

\section{B. Behavioral Evidence}

Survey measures of subjective well-being are not the only evidence that people care strongly about relative income. Unlike psychologists, who often rely on survey evidence, economists prefer behavioral evidence when attempting to make inferences about what people care about. The relevant literature is not extensive, but there are several studies that shed light on the strength of concerns about relative income.

1. The sisters study. In a recent paper, the economists David Neumark and Andrew Postlewaite investigate how individual labor supply decisions depend on the incomes of important reference group members. ${ }^{64}$ They argue that if someone cares strongly about how her income compares with the incomes of others, an increase in others' incomes will cause her to become more likely to seek employment, or more likely to work longer hours if she is already employed. The difficulty in testing such predictions has always been that it is hard to know whose incomes really matter to the decision maker. Most people presumably care most about the incomes of people with

\footnotetext{
${ }^{60}$ See, e.g., Richard Thaler, Quasi-Rational Economics (1991).

${ }^{61}$ See id; Jennifer Arlen et al., Endowment Effects, Other-Regarding Preferences, and Corporate Law for a recent overview.

${ }^{62}$ See Truman Bewley, Why Wages Don't Fall During A Recession (2000).

${ }^{63}$ See, e.g., George Loewenstein and David Schkade, Wouldn't It Be Nice? Predicting Future Feelings, in Well-Being: The Foundations of Hedonic Psychology 85 (Daniel Kahneman et al eds 1999).

${ }^{64}$ David Neumark and Andrew Postlewaite, Relative Income Concerns and the Rise in Married Women's Employment, J. Public Economics (70)1 (1998) pp. 157-183
} 
whom they associate most closely. Unfortunately, researchers seldom have reliable data about who knows whom, much less about which specific individuals people care most about.

Neumark and Postlewaite cleverly finesse this problem by examining the behavior of sisters. The specific question they pose is this: Does a woman's decision about whether to work outside the home depend on her sister's economic circumstances? According to economic orthodoxy, which holds that only her own absolute income matters to her, it would not. But Neumark and Postlewaite find differently for a large sample of women whose sisters are not employed. Specifically, they find that such a woman is 16 to 25 percent more likely to work outside the home if her sister's husband earns more than her own husband. ${ }^{65}$ This is strong evidence that relative position matters to both perceived well-being and actual behavior.

2. Employer and employee behavior. Surveys of employers and employees suggest that salaries depend a great deal on what employees think other people are receiving, and that perceptions of relative position have large effects on morale. ${ }^{66}$ "Few workers have a precise notion of market wages or wages that are fair in some absolute sense. Rather, they make comparisons with their own past pay and with the pay of coworkers." ${ }^{67}$ As we will discuss in more detail below, the internal wage structure of firms is highly responsive to this point, partly because employers do not want to encourage bickering and shirking by making some workers think that they are being underpaid relative to coworkers. In the words of an official responsible for international job placement, "Inequity causes disharmony. Employees want more money if a new person is paid more than they are." ${ }^{68}$ In the words of the director of a small company, "I have had difficulty with people receiving different pay who had similar skills and worked in different parts of the building. . . . They felt underpaid and undervalued." 69 Many companies respond to people's concerns about relative economic position with relatively rigid "grade and step systems." Some companies respond by creating a norm against public discussion of salaries, on the theory that people are likely to be happy enough with their own, but would be less happy if they found themselves making comparisons to others. ${ }^{70}$ Strategies of this sort would be unintelligible if absolute position was all or almost all that matters.

3. The ultimatum game. Concern about relative wealth also helps to explain some otherwise puzzling behavior in interpersonal bargaining contexts. Consider, for example,

\footnotetext{
${ }^{65}$ Ibid, Table 3.

${ }^{66}$ A recent, detailed treatment is Truman Bewley, Why Wages Don't Fall DuringA Recession (2000).

${ }^{67}$ Id. at 310 . The point may be most familiar in professional sports, where athletes seek higher salaries on the basis of the salary set by relevant others. Often such athletes contend that their demands are not really "about money" but are really "about respect." These claims are frequently ridiculed on the ground that "respect" is a disguise for what really matters, which is "the money." If we are right, there is no disguise here; money is a proxy for "respect." Labor market behavior shows that this is a pervasive phenomenon, not limited to professional sports. (Imagine if you discovered that the median salary in your workplace, for people like you, was $5 \%$ higher than your salary.)

${ }^{68}$ Id. at 81.

${ }^{69} \mathrm{Id}$. at 80 .

${ }^{70}$ As it happens this is the practice at the University of Chicago Law School; there is an exceptionally strong norm against public discussion of salaries, even among good friends. The evident basis of the norm is to prevent dissatisfaction about relative position in the face of satisfaction with absolute position.
} 
an elegant experiment known as the "ultimatum game." ${ }^{71}$ The game is played by two players, "Proposer" and "Responder." It begins with Proposer being given a sum of money (say, \$100) that he must then propose how to divide between himself and Responder. Responder then has two options: 1) he can accept, in which case each party gets the amount proposed; or 2) he can refuse, in which each party gets zero and the $\$ 100$ goes back to the experimenter.

If Proposer believes that Responder cares only about absolute wealth, his own wealth-maximizing strategy is clear: he should propose $\$ 99$ for himself and $\$ 1$ for Responder (only integer dollar amounts are allowed). If Proposer's assumption about Responder is correct, Responder will accept this one-sided offer because he will reason that getting $\$ 1$ is better than getting nothing. This is the standard economic prediction.

But suppose that Responder cares not only about absolute but also relative wealth levels - about the relative division of money as between the two. Responder might then refuse the one-sided offer, even though he stands to gain from it in absolute terms, because he finds the relative terms so distasteful. In fact, refusals of one-sided offers are widely observed. Responders routinely reject offers that do not involve splits of 50-50 or 60-40 -- even when the stakes are large, as in games played for several months' salary in poor nations. ${ }^{72}$ Likely anticipating responders' behavior, proposers routinely offer splits of $50 \%-50 \%$ and $60 \%-40 \%$. Proposers rarely offer less than $20 \%$, and responders rarely accept less than that amount. The existence of such results in games with large stakes demonstrates that the outcomes cannot be discounted on the ground that the money involved is a small fraction of total wealth.

To be sure, relative position is not all that matters in the Ultimatum Game. Much of the behavior is driven by Responders' beliefs about the motivations of Proposers. When the experiment is altered to make it seem as if Proposers have earned the right to be Proposers, more unequal divisions are acceptable; the same is true when Proposers' options are narrowed, making an unequal division (say, 80-20) seem more fair in light of the alternatives (say, 10-10 or 10-90). ${ }^{73}$ Thus a preference for good relative position does not explain all of what occurs in the game; ensuring a fair outcome, which may or may not call for good relative position, is often the driving factor. But relative position also counts for many participants, so much so that "difference aversion" appears to motivate a significant percentage of participants. That is enough for our basic claim here. ${ }^{74}$

An obvious irony is that the effect of Proposer's believing that Responder cares about relative wealth is to boost substantially the amount that Proposer offers Responder. By virtue of his concern about relative wealth, Responder becomes a much more effective bargainer. Thus the outcomes of the ultimatum game strongly support the proposition that

\footnotetext{
${ }^{71}$ See Werner Guth, Rolf Sdhmittberger, and Bernd Schwarze, An Experimental Analysis of Ultimatum Bargaining, 3 J. of Economic Behavior and Organization 367-68 (1982).

${ }^{72}$ For example, see Colin Camerer and Richard Thaler, Ultimatums, Dictators, and Manners, 9 J Ec Persp. 209 (1995); Alvin Roth et al. Bargaining and Market Behavior in Jerusalem, Ljubljana, Pittsburgh, and Tokyo, 81 Am. Ec. Rev. 1068 (1991); for a recent overview, see Jennifer Arlen et al., Endowment Effects, Other-Regarding Preferences, and Corporate Law (forthcoming 2000).

73 See Gary Charness and Matthew Rabin, Social Preferences: Some Simple Tests and A New Model (unpublished manuscript 2000, available from Social Science Research Network).

${ }^{74}$ See id.
} 
relative income, not only absolute income, matters a great deal, ${ }^{75}$ and indeed that this concern for relative position can strengthen bargaining positions.

4. Status experiments. Sheryl Ball and her co-authors have shown that even simple laboratory manipulations of relative position can have profound implications for the terms of market exchange. ${ }^{76}$ In one experiment, for example, they awarded half of their subjects "stars" on the basis of their performance on a transparently meaningless quiz. Following these awards, subjects were given objects of known value and allowed to exchange these objects with one another for cash. The subjects who received stars consistently received better terms - that is, they bought at lower prices and sold at higher prices-when they exchanged goods with subjects who did not receive stars. It seems clear that people with higher relative position in a salient context do better in apparently unrelated contexts, simply because of that higher position.

\section{Biological and Physiological Evidence}

There is evidence that relative position affects health and even fundamental biochemical processes in the nervous system. For reasons that remain poorly understood, and not easily traced to a simple causal mechanism, high relative position is correlated with good health, and low relative position with worse health - holding absolute income constant. ${ }^{77}$

In a study involving 19 groups of adult vervet monkeys, McGuire et al. found a relevant mechanism: the dominant member in each group had roughly 50 percent higher concentrations of the neurotransmitter serotonin, which affects mood and behavior in a variety of ways. ${ }^{78}$ They also showed that this difference was both a cause and an effect of high status. ${ }^{79}$ Fortunately the evidence is not limited to monkeys; McGuire and his

\footnotetext{
${ }^{75}$ As noted in the text, we do not contend that the outcomes of the ultimatum game can be explained solely on this basis. The responder's perception of the proposer's intentions, and character, is therefore an important factor in these experiments. See Rabin, supra note; Sally Blount, When Social Outcomes Aren't Fair: The Effect of Causal Attributions on Preferences," 63(2) Organizational Behavior and Human Decision Processes 131, (1995), for instructive treatments.

${ }^{76}$ Sheryl Ball and Catherine Eckel. Status and Discrimination in Ultimatum Games: Stars Upon Thars, Virginia Polytechnic Institute Department of Economics mimeo, 1994; Sheryl Ball, Catherine Eckel, Philip Grossman, and William Zame, Status in Markets, Department of Economics Working Paper, Virginia Polytechnic Institute, January 1996.

${ }^{77}$ See Robert Frank, Luxury Fever 142-43 (1999).

${ }^{78}$ See Michael McGuire, M. Raleigh, and G. Brammer, Sociopharmacology, 22 Annual Review of Pharmacological Toxicology, 643, 643-61 (1982).

${ }^{79}$ To do this, they removed the initially dominant animal from each group and placed him in an isolation cage. Shortly thereafter, a new individual established dominance within each group, and after roughly 72 hours passed, serotonin concentrations in the newly dominant animal rose to the levels seen in the formerly dominant animal. At the same time, the serotonin concentrations in the formerly dominant animal fell to the level associated with subordinate status. When the initially dominant animal was returned to the group, he reasserted dominance and serotonin concentrations in both the originally dominant and interim dominant animals responded accordingly. See Michael J. Raleigh, and Michael T. McGuire, Serotonin, Aggression, and Violence in Vervet Monkeys, 146-58 in The Neurotransmitter Revolution: Serotonin, Social Behaivor, and the Law, Roger Masters and Michael McGuire, eds., Carbondale, IL: Southern Illinois University Press (1994). Michael Raleigh and his co-authors also found that animals were more likely to ascend in the social hierarchy after having been given drugs that boost concentrations of serotonin. See Michael Raleigh, Gary Brammer, Edward Ritvo, and Edward Geller, Effects of Chronic Fenfluramine on Blood Serotonin, Cerebrospinal Metabolites, and Behavior in Monkeys, 90 Psychopharmacology 503 (1986).
} 
colleagues have also found elevated serotonin levels in the leaders of college fraternities and athletic teams. ${ }^{80}$ In another study, Douglas Madsen finds that the status-serotonin relationship is positive for some groups of male college students. ${ }^{81}$

Like dopamine, norepinephrine, and other neurotransmitters, serotonin affects mood and behavior in a variety of ways. Within limits, having elevated serotonin concentrations is associated with enhanced feelings of well-being. Serotonin deficiencies are associated with a variety of affective disorders, including irritability, sleep disorders, mania, and depression. ${ }^{82}$ Recent work suggests that serotonin deficiencies are also strongly linked with impulsive aggression and suicide attempts. ${ }^{83}$

In males, concentrations of the sex hormone testosterone appear to have a relationship with status similar to the one seen for serotonin. Reductions in status thus tend to be followed by reductions in plasma testosterone levels, whereas these levels tend to rise following increases in status. ${ }^{84}$ A player who wins a tennis match decisively, for example, experiences a post-match elevation in plasma testosterone, and his vanquished opponent experiences a post-match reduction. ${ }^{85}$ And as with serotonin, there is some evidence from primate studies that elevated concentrations of testosterone facilitate behaviors that help achieve or maintain high status. ${ }^{86}$

To be sure, it is not simple to extrapolate from such data to judgments about the importance of relative position with respect to income (and other goods) within all human contexts and societies; socialization matters a great deal and can undoubtedly increase or decrease people's concern with their standing in the group. But there is at least plausible reason to think that a high relative position is associated with desirable physiological effects, and that low relative position is associated with undesirable ones.

There is a more speculative grounds to think that something like this is true. If we adopt the biologist's view that human motivation is shaped in part by the forces of natural selection, it is no surprise that people would care so strongly about relative resource holdings. Even in a famine, for example, there is always some food available, and the question of who gets it is settled largely by relative entitlements. ${ }^{87}$ Concern about relative

\footnotetext{
${ }^{80}$ McGuire, personal communication to Robert Frank (1998).

${ }^{81}$ Douglas Madsen, Serotonin and Social Rank Among Human Males, in The Neurotransmitter Revolution: Serotonin, Social Behaivor, and the Law, Roger Masters and Michael McGuire, eds., Carbondale, IL: Southern Illinois University Press, 146-158 (1994).

${ }^{82}$ Alec Coppen, Role of Serotonin in Affective Disorders, in J. Barchas and E. Usdin, eds., Serotonin and Behavior, (Academic Press, 1973); see also the summary discussion in J. Barchas. and E. Usdin, eds., Serotonin and Behavior, (Academic Press, 1973).

${ }^{83}$ Emil F. Coccaro, The Biology of Aggression, 38 Scientific American, 38 (1995). The drug Prozac, widely prescribed for depression and other mood disorders, is a serotonin uptake inhibitor, which means that it increases the effective concentrations of serotonin in the brain.

${ }^{84}$ See, for example, Allan Mazur, Physiology, Dominance, and Aggression in Humans, in A. Goldstein, ed., Prevention and Control of Aggression, (Pergamon, 1983); Allan Mazur and T. Lamb. Testosterone, Status, and Mood in Human Males, 14 Hormones and Behavior 236 (1980); and M. Elias, .Serum Cortisol, Testosterone and Testosterone Binding Globulin Responses to Competitive Fighting in Human Males, 7 Aggressive Behavior 215 (1984).

${ }^{85}$ Mazur and Lamb, supra.

${ }^{86}$ See Rose, Bernstein, and Gordon, (1975).

${ }^{87}$ See Amartya Sen, Poverty and Famines (1981).
} 
position is also adaptive insofar at it prods people to monitor how they are doing relative to their competitors and to boost their effort levels if they start falling behind. ${ }^{88}$

In sum, evidence from several disciplines strongly suggests that interpersonal comparisons are an important determinant of both physical and psychological well-being. Such comparisons take place along many dimensions other than income. In what follows, however, our focus will be on comparisons in the income domain. We emphasize income comparisons because relative economic position is of obvious importance and because positional concerns typically loom larger with income than with the goods that regulation attempts to provide (safety, leisure time, leave to take care of children and ailing relatives). Our basic objection is that the conventional estimates used in cost-benefit analysis of health and safety regulation are derived from models that assume, quite implausibly, that people do not care at all about relative economic position. This produces a serious distortion, as we shall now see.

\section{How Concerns about Relative Position Affect Willingness To Pay}

There is an initial question about the use of willingness to pay as a measure for many regulatory benefits: Who is actually going to pay for them? Suppose, for example, that government proposes to impose workplace safety requirements or to require all employers to provide a certain period of leave time for new parents. Will the cost of these requirements be borne by (a) workers, in the form of reduced salary (or other benefits), or (b) consumers, in the form of increased prices, or (c) firms, in the form of reduced profits (and perhaps reduced compensation for high-level executives), or (d) the unemployed, in the form of lost job opportunities?

Though theoretical considerations can provide useful guidance,${ }^{89}$ this is of course an empirical question; and as a general rule, decisive empirical evidence is lacking. There is, however, evidence that at least in some cases, requirements of this sort do result in lower wages. The workers' compensation programs of the early twentieth century, for example, appear to have resulted in something like a dollar-for-dollar reduction in the earnings of nonunionized workers; the parental leave program of the early 1990s appears to have had a similar effect. ${ }^{90}$ For the sake of discussion, we make a simple assumption here, without insisting that the assumption is correct: The people who benefit from regulatory programs will also have to pay for those benefits. We suggest that even if they do have to pay for those benefits, existing methods for eliciting their willingness to pay substantially understate the appropriate amount, from the beneficiary's own point of view.

\footnotetext{
${ }^{88}$ The alternative of operating at maximum effort levels at all times is less efficient in that people tend to do better by conserving their energy when environmental conditions are not stressful for use when the threats to survival are more immediate.

${ }^{89}$ For an overview of the theoretical considerations, see Lawrence H. Summers, Some Simple Economics of Mandated Benefits, 79 Amer. Econ. Rev. (Papers \& Proceedings) 177 (1989).

${ }^{90}$ See Jonathan Gruber, The Incidence of Mandated Maternity Benefits, 84 Am. Econ. Rev. 622 (1994), and Price Fishback and Shawn Kantor, Did Workers Pay for the Passage of Workers' Compensation Laws, 110 Q J Econ. 713 (1995) (finding substantial wage offsets): "Analysis of the effect of the introduction of workers' compensation on wages shows that in the coal and lumber industries, workers experienced substantial wage offsets. In the coal industry the offsets were large enough to cover not only the expected monetary value the benefits, but also the employers' costs of purchasing the insurance to provide those benefits." Id. at 736 .
} 
A. The Distortion

1. Smith and Jones. To illustrate how concerns about relative position affect willingness to pay for an amenity such as workplace safety, we begin by working through a simple, stylized example of an employment decision confronting two workers, Smith and Jones. Also for simplicity's sake, we assume that each gets satisfaction from, or cares about, three things-his income, his safety on the job, and his position on the economic ladder. We make no assumptions about why he cares about that position, though we will say a few words on the point below. The choice the two confront is between a safe job that pays $\$ 300 /$ wk and a risky job that pays $\$ 350 / w k$. The value of safety to each is $\$ 100 / \mathrm{wk}$, and each evaluates relative income as follows: Having more income than his neighbor provides the equivalent of $\$ 100 /$ wk worth of additional satisfaction; having less income than his neighbor means the equivalent of a $\$ 100 / \mathrm{wk}$ reduction in satisfaction; and having the same income as his neighbor means no change in the underlying level of satisfaction. (For purposes of understanding the general point, the specific numbers do not matter; the same point could be illustrated in any number of ways.) The question is: Which jobs will Smith and Jones choose?

If we viewed each person's decision in isolation, the normatively correct choice would be the safe job. Although it pays $\$ 50 /$ wk less than the risky job, the extra safety it provides is worth $\$ 100 / \mathrm{wk}$, by assumption. So if we abstract from the issue of concern about relative income, the value of the safe job is $\$ 400 /$ wk (its $\$ 300$ salary plus $\$ 100$ worth of safety), which is $\$ 50 /$ wk more than the $\$ 350$ value of the risky job.

Once we incorporate concerns about relative income, however, the logic of the decision changes in a fundamental way. Now the attractiveness of each choice depends on the job chosen by the other. The four possible combinations of choices and the corresponding levels of satisfaction are shown in Table 3.

\begin{tabular}{|c|c|c|}
\hline & \multicolumn{2}{|c|}{ Smith } \\
\hline & safe job @ \$300/wk & unsafe job @ \$350/wk \\
\hline safe job@\$300/wk & $\$ 400 /$ wk each & $\begin{array}{l}\$ 300 / \text { wk for Jones } \\
\$ 450 / \text { wk for Smith }\end{array}$ \\
\hline Jones & & \\
\hline unsafe job @\$350/wk & $\begin{array}{l}\$ 450 / \text { wk for Jones } \\
\$ 300 / \text { wk for Smith }\end{array}$ & $\$ 350 /$ wk each \\
\hline
\end{tabular}

Table 3. The Effect of Concerns about Relative Income on Worker Choices Regarding Safety

Suppose, for example, that Jones chooses the safe job. If Smith then chooses the unsafe job, he ends up with total satisfaction worth $\$ 450-\$ 350$ in salary plus $\$ 100$ from having more income than Jones. Jones, for his part, ends up with only $\$ 300$ worth of total satisfaction- $\$ 300$ in salary plus $\$ 100$ from safety minus $\$ 100$ from having lower 
income than Smith. Alternatively, suppose Jones chooses the unsafe job. Then Smith again does better to accept the unsafe job, for by so doing he gets $\$ 350$ worth of satisfaction rather than only $\$ 300$. Since the payoff matrix is symmetric, each player's dominant strategy is to choose the unsafe job.

Armed with the standard theory of revealed preference, an analyst who observed these choices would conclude that Smith and Jones must value the extra safety at less than $\$ 50 / w k$. After all, they could have chosen the safe job by sacrificing only $\$ 50 /$ wk in wages, yet they chose not to do so. Their choices do not imply, however, that each values safety at less than $\$ 100 / w k$. Note that if each chooses a safe job, each will get $\$ 400$ worth of total satisfaction- $\$ 300$ of income, $\$ 100$ worth of satisfaction from safety, and zero satisfaction from relative position. If each had instead chosen the unsafe job, each would have had $\$ 350$ of income, zero satisfaction from safety, and each would again have had the same level of income, so again zero satisfaction from relative position. If we compare the upper-left cell of Table 3 to the lower-right cell, then, we can say unequivocally that Smith and Jones would be happier if each took a safe job at lower income than if each chose an unsafe job with more income. By assumption, the extra safety is worth more $(\$ 100)$ than its cost $(\$ 50)$.

The discrepancy arises from a standard problem: the job-safety choice confronts workers with a prisoner's dilemma. If our two workers could choose collectively, they would pick the safe job, an outcome they prefer to what happens when they choose independently.

The bias against safety illustrated in this example stems from our assumption that well-being depends on relative income but not on relative safety. In practice, however, relative safety levels may also matter, since a given risk in the workplace is likely to seem less objectionable in environments in which other similar risks are common. A bias against workplace safety would nonetheless result if concerns about relative income were greater, on average, than concerns about relative safety. Such a difference would be expected on grounds that interpersonal safety comparisons are often precluded by the fact that safety levels are difficult to observe. Such a difference might also be justified if, as seems plausible, safety, far more than income, is by its nature a good whose value depends largely, though of course not only, on absolute value. Hence what we will be suggesting here is that many regulatory goods are less positional than income, both because they are less easily observed and because people care about them more or less independently of what others have or do. For some such goods, the intuition here should be especially clear. The opportunity to spend time with an infant, for example, is valuable regardless of how many other people have that opportunity.

2. The real world. In practice, workers must choose among many jobs, each with a different wage and level of workplace safety. As in the example just considered, concerns about relative position in this more realistic setting will cause workers to choose jobs that offer higher wages and lower safety levels than they would have chosen in the absence of concerns about relative position. ${ }^{91}$ From the individual worker's vantage point, the higher wages that accompany riskier jobs promise an improvement in both absolute and relative consumption. Yet when other workers make similar choices, the relative advance each hoped to achieve does not materialize. The incentive problem is

\footnotetext{
${ }^{91}$ For simplicity, we are assuming here that the reference group consists of workers in the same firms; of course people are not so limited in their reference groups. We discuss some complications below.
} 
analogous to the familiar stadium metaphor: all stand up to get a better view, yet no one sees any better than if all had remained seated.

The upshot is that conventional measures of willingness to pay understate the social benefits of additional workplace safety. In typical applications, cost-benefit analysts estimate the value of workplace safety by means of hedonic pricing models, which examine how wages vary with workplace injury levels or mortality rates. ${ }^{92}$ For example, a hedonic pricing model might estimate that, after controlling for other relevant factors, wages rise by 2 percent when the probability of dying in a workplace accident falls by one in a thousand. Analysts would infer from such an estimate that a worker earning $\$ 50,000$ per year would be would be willing to pay $\$ 1000$ per year for a 0.001 reduction in the probability of death. From that price they would then extrapolate that the statistical value of a human life is $\$ 1,000 / 0.001=\$ 1$ million.

But this procedure understates the social value of risk reduction. What the hedonic pricing model really tells us is that a $\$ 50,000$-a-year worker would pay $\$ 1,000$ for a 0.001 reduction in the probability of dying, even though the expenditure would reduce his consumption significantly relative to those who did not make similar expenditures on safety. The implication is that if the worker cares about relative position, he would be willing to pay more than $\$ 1,000$ for the additional safety if the transaction did not entail a reduction in relative consumption (as would be true if all workers bought additional safety).

\section{B. Removing the Distortion: The Elasticity of Position and A Simple Solution}

What has been said thus far is sufficient to show that there is a distortion; but it does not establish its size. How big is the distortion, and how might a cost-benefit analyst attempt to correct for it? To answer these questions, we need to know how much an individual's own income would have to increase in order to fully compensate for any negative effects caused by a general rise in the incomes of others. More precisely, we define the elasticity of position as the percentage by which an individual's own income would have to rise in order to fully compensate for the effects of a 1 percent rise in the incomes of others in his social comparison set. For example, if an individual would be indifferent between the status quo and a change in which his income rose 0.5 percent while others' incomes rose 1 percent, the elasticity of position would be 0.5 .

One way to try to estimate the elasticity of position is to employ results from surveys in which subjects are periodically asked questions such as "What is the smallest amount of money a family of four needs to get along in this community?"93 In one series of surveys, the median response to this question-expressed as a percentage of the current year's average disposable income for a family of four-varied between 52 percent and 33 percent, with little discernable trend. Similar patterns have been found in other surveys. For example, Eugene Smolensky found that the median values of reported estimates of "minimum-comfort" budgets for workers in New York City have hovered around half of average per-capita national income since the beginning of the 20th

\footnotetext{
${ }^{92}$ See, for example, Richard Thaler and Sherwin Rosen, The Value of Saving a Life: Evidence from the Labor Market, in N. Terleckyj, ed., Household Production and Consumption, 265-71 (NBER, 1976).

${ }^{93}$ Benjamin Friedman, 2000 (forthcoming).
} 
century. ${ }^{94}$ Lee Rainwater found that for surveys taken between 1950 and 1986, the "income necessary to get along" has grown at about the same rate as per-capita national income. ${ }^{95}$

These findings suggest that the elasticity of position is 1.0 -or that an individual's income would have to grow in the same proportion as overall income to maintain a constant level of subjective well being. To say that the elasticity of position is 1.0 amounts to saying that relative income is the only important economic determinant of subjective well-being. Although this conclusion is broadly consistent with the survey evidence reviewed by Richard Easterlin, it is nonetheless clearly an extreme position. If we accept this conclusion at face value, the implication is that safety and other nonpositional regulatory benefits can be provided essentially for free!

For the reasons earlier discussed, however, we reject the conclusion that only relative income matters, and indeed other survey evidence appears to suggest an elasticity of position significantly less than one. The most conservative estimate we could find comes from a study by three Dutch economists. Using data collected in The Netherlands, van de Stadt, Kapteyn, and van de Geer ( $\mathrm{vKv}$ ) estimate an elasticity of position equal to roughly $1 / 3$ - that is, that a family would need about a 3.3 percent increase in its real income to compensate for a 10 percent increase in the incomes of all others in the community. ${ }^{96}$ For illustrative purposes, we employ this estimate to construct a simple multiplier for adjusting willingness-to-pay values generated by hedonic pricing models.

Consider a hypothetical world in which each individual works as an independent contractor and must decide how to apportion his income between safety and other goods. Suppose that in this world we observe that individual workers are willing to give up 2 percent of their incomes each year in exchange for a 1 in 1000 reduction in the probability of dying in a workplace accident. A worker earning $\$ 50,000$ per year would thus be willing to pay $\$ 1000$ per year for the additional safety, even though the expenditure would entail a 2 percent reduction in his relative standard of living. The vKv estimate suggests that this worker would be willing to pay roughly $\$ 333$ more for the same increment in safety if he could be assured that his relative income would be unaffected by the expenditure - as would be the case, for example, if everyone else made similar expenditures on safety. For the hypothetical world described, an adjustment based on the vKv survey data would thus call for an upward revision by 33 percent in the willingness to pay values inferred from hedonic pricing models. For example, if those models produced a value of life of $\$ 5$ million, the right number would be closer to $\$ 6.7$ million - to say the least, a substantial difference for purposes of regulatory law.

In practice, of course, most workers do not decide as independent contractors how much to spend on safety. Typically, they work in firms in which the level of safety expenditure is the same for each worker in a given occupation. In such environments, joining a group with high expenditures on safety does not entail a loss of relative income

\footnotetext{
${ }^{94}$ Eugene Smolensky, The Past and Present Poor, in The Concept of Poverty, Task force on Economic Growth and Opportunity, Washington, DC: Chamber of Commerce of the United States, 1965.

${ }^{95}$ Lee Rainwater, Poverty and Equivalence as Social Constructions, Luxembourg Income Study Working Paper 55, 1990.

${ }^{96}$ Huib van de Stadt, Arie Kapteyn, Sara van de Geer (1985), The Relativity of Utility: Evidence from Panel Data, Review of Economics and Statistics 67, 179-187. See also B.M.S. van Praag and Arie Kapteyn, Further Evidence on the Individual Welfare Function of Income: An Empirical Investigation of the Netherlands, 4 European Economic Review 33 (1973).
} 
vis-à-vis coworkers (although it does still mean having lower income relative to members of other groups). If one's personal reference group consisted entirely of one's coworkers, the distortion caused by concerns about relative position would not arise, and conventional hedonic estimates would not be biased. Typically, however, an individual's personal reference group contains not just coworkers, but also friends, neighbors, family members, and other acquaintances who are not in a position to participate in collective decisions about safety expenditures.

For the sake of illustration, we consider the intermediate case of a worker whose personal reference group consists equally of coworkers and non-coworkers. For such a worker earning $\$ 50,000$ per year, a $\$ 1,000$ per year expenditure on safety reduces relative income by an average of 1 percent (a zero percent reduction vis-à-vis his coworkers and a 2 percent reduction vis-à-vis others). Our adjustment based on the vKv estimate would then be only half as large as before. That is, the worker would be willing to pay roughly $\$ 167$ more for the same increment in safety if he could be assured that his income relative to relevant non-coworkers would be unaffected by the expenditure-as would be the case, again, if everyone else made similar expenditures on safety. For this illustrative case, an adjustment based on the vKv survey data would call for an upward revision by 17 percent in the willingness to pay values inferred from hedonic pricing models. For example, if those models produced a value of life of $\$ 5$ million, the adjusted estimate would be almost $\$ 6$ million.

\section{An Alternative Approach}

1. An overview. Many analysts may feel uncomfortable adjusting benefit estimates on the basis of responses to survey questions regarding subjective well-being. In this section we examine an alternative procedure that rests not on surveys but on objective market data - on what behavior within markets reveals about people's value of higher rank, or elasticity of position. If people care about relative position not just in a global sense, but also within the context of specific groups to which they belong, it is possible to infer the value of relative income by examining the relationship between wages, local rank, and productivity among groups of co-workers. ${ }^{97}$

The full story is somewhat technical. For those uninterested in the details, the simple version begins with the suggestion that in the labor market, compensating wage differentials must be and are paid, not only for higher risks ${ }^{98}$ and less vacation time, but also for lower relative positions within firms. ${ }^{99}$ Just as in the context of risk-taking, where the use of compensating wage differentials is well-established, ${ }^{100}$ so too here. Actual labor market behavior can be used to ascertain the amount that people are willing to pay to avoid occupying positions of low rank vis-à-vis their coworkers. Compensating wage differentials, once ascertained, can be used to adjust private willingness to pay by incorporating concerns about relative position. We attempt an exercise to show how such differentials might be calculated, with the qualification that a full analysis would require

\footnotetext{
${ }^{97}$ R. H. Frank, Are Workers Paid Their Marginal Products?, 74 American Economic Review 549 (1984).

${ }^{98}$ See W. Kip Viscusi, Fatal Tradeoffs (1992).

${ }^{99}$ Of course different people will have different tastes on this count, as we discuss; some people do not much care about a high relative position, and some people even dislike having much more income than their coworkers. We use survey and labor market evidence to capture aggregates.

${ }^{100}$ See id.
} 
access to a fuller and more up-to-date labor market data than those used here. What is important is the principle and the basic inquiry, not the details.

2. In general: how rank affects labor market choices. Standard labor market theories, which assume that workers do not care about relative position, assert that wage rates will track productivity differences on a one-to-one basis. Thus if one worker contributes $\$ 10 / \mathrm{hr}$ more than another to the employer's bottom line, the first worker should earn precisely $\$ 10 / \mathrm{hr}$ more than the second. Yet many firms follow strict salary formulas based on experience, education, and length of tenure within the firm, even when there are large visible differences in the productivity of workers paid the same under these formulas.

Such patterns can be accounted for, however, by a simple amendment to the standard models. The amendment rests on two assumptions: 1) other things being equal, most people prefer high-ranked to low-ranked positions among their coworkers; and 2) no one can be forced to remain in a firm against his or her wishes. ${ }^{101}$

Our account begins with the observation that, by the laws of simple arithmetic, not everyone's preference for high rank in the wage distribution of his firm can be satisfied. After all, only 50 percent of the members of any group can be in the top half. But if people are free to associate with whomever they please, why are the lesser-ranked members of groups content to remain? Why don't they all leave and attempt to form new groups of their own in which they would no longer be near the bottom? Many workers undoubtedly do precisely that. And yet we also observe many stable, heterogeneous groups. Not all accountants at General Motors are equally talented; and in every law firm, some partners attract much more new business than others. If everyone prefers to be near the top of his or her group of coworkers, what holds these heterogeneous groups together?

An important part of the answer is that their low-ranked members receive extra compensation - partly from a prestigious association, partly from an advantageous wage structure. If they were to leave, they would gain by no longer having to endure low rank. By the same token, however, the top-ranked members would lose, because they would no longer enjoy high rank. If their gains from having high rank are larger than the costs borne by members with low rank, it does not make sense for the group to disband. Everyone can do better if the top-ranked workers induce their lesser-ranked colleagues to remain by sharing some of their pay with them.

Of course, not everyone assigns the same value to having high rank. Some people care little or not at all about high relative rank. Some people actually dislike having more money, or a lot more money, than their coworkers. Others consider high relative rank extremely important. Some people do not much care about high rank, but abhor low rank. Just as people diverge on other aspects of a compensation package, such as parental leave and vacation time, so too they diverge on the value of a high relative rank. Those who care little or less about high rank will do best to join firms in which the wage is high even if, or because, they are less productive than most workers on the scene. As lesser-ranked members in these firms, they will receive extra compensation. People who care most strongly about rank, by contrast, will want to join firms in which most other workers are

\footnotetext{
${ }^{101}$ For a formalization of the argument that follows, see R. H. Frank, Interdependent Preferences and the Competitive Wage Structure, 15 The Rand Journal of Economics, 510, 510-520 (1984).
} 
less productive than themselves. For the privilege of occupying top-ranked positions in those firms, they will have to work for less than the value of what they produce.

Workers can thus sort themselves among a hierarchy of firms in accordance with their demands for within-firm status. Figure 1 depicts the menu of choices confronting workers whose productivity takes a given value, $\mathbf{M}_{0}$. The heavy lines represent the wage schedules offered by three different firms. They tell how much a worker with a given productivity would be paid in each firm. The average productivity level is highest in firm 3 , next highest in firm 2, and lowest in firm 1. The problem facing persons with productivity level $\mathrm{M}_{0}$ is to choose which of these three firms to work for.

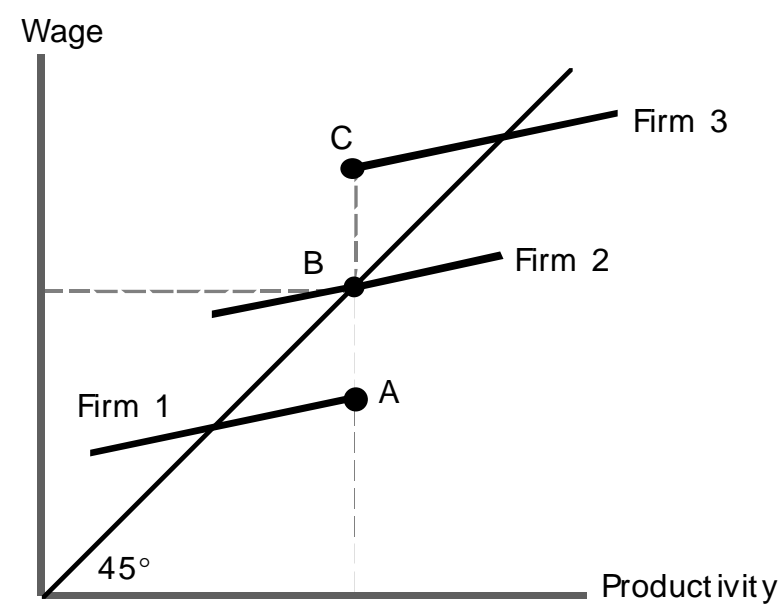

Figure 1. The Wage Structure when Local Status Matters.

Workers who care most about local rank will want to "purchase" high-ranked positions such as the one labeled "A" in Firm 1. In such positions, they work for less than the value of what they produce. By contrast, those who care least about local rank will elect to receive wage premiums (of one or another magnitude) by working in lowranked positions such as the one labeled "C" in Firm 3. Workers with moderate concerns about local rank will be attracted to intermediate positions such as the one labeled "B" in Firm 2, for which they neither pay nor receive any compensation for local rank.

Note also in Figure 1 that even though not every worker in each firm is paid the value of what he or she produces, workers taken as a group nonetheless do receive the value of what they produce. The extra compensation received by each firm's low-ranked workers is exactly offset by the shortfall in pay of its high-ranked workers. There is thus an implicit market for high-ranked positions in the firm. Buyers in this market are those who purchase the right to occupy such positions by agreeing to work for less than the value of what they produce. Sellers in this market are those who agree to occupy lowranked position (without which high-ranked positions cannot exist) in return for being paid more than the value of what they produce. By observing the deviations between pay and productivity within groups of workers in the firm, the analyst can infer the monetary value that people assign to high local rank.

3. Compensating differentials for relatively lower rank. How large are the compensating wage differentials for lower rank within the firm? If we knew the answer to that question, we could use it in an attempt to estimate the monetary cost of a reduction 
in relative position - the essential piece of information we need to adjust conventional estimates of the monetary value of safety and other workplace amenities. Of course the amount that workers are willing to pay for high local rank will be different for different occupations. In occupations in which coworkers do not associate closely with one another, people will not be willing to pay much for a high-ranked position. After all, the comparisons that matter most are those between people who interact most intensively. The price paid for high rank (and received for low rank) will be highest in occupations in which coworkers work closely together for extended periods.

The amended model predicts that the wage will rise by less than a dollar for each extra dollar of value produced, and that the difference between productivity and pay will increase with the extensiveness of interaction between coworkers. ${ }^{102}$ The predictions of the standard model are contrasted with those of the amended model in Figure 2.

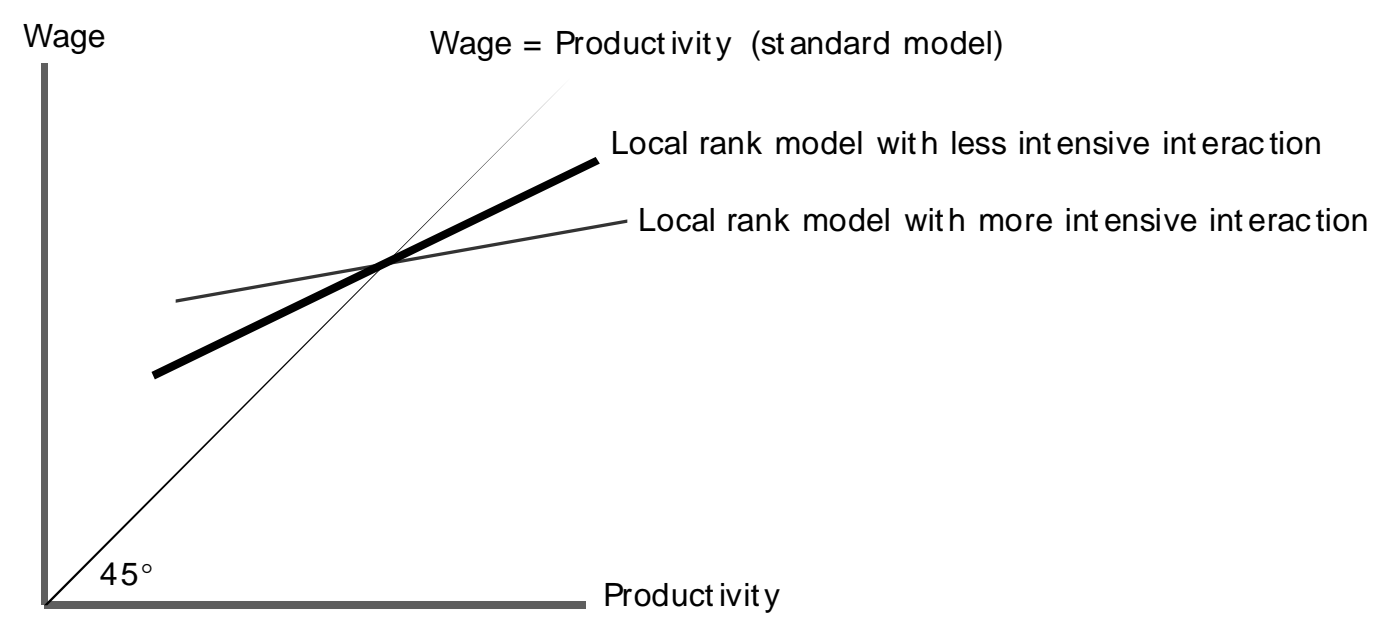

Figure 2. Wage Schedules and the Intensity of Interaction.

Table 4 presents estimates of the rates at which earnings rise with productivity for three occupations. ${ }^{103}$ The occupations are listed in increasing order of closeness of interaction. Real estate salespersons, who have the least intensive contact, pay the lowest amounts for high-ranked positions. At the other end of the spectrum, research chemists, who work together in close-knit groups for extended periods, pay very large sums indeed.

102 Of course, factors other than an implicit market for local rank might also contribute to wage compression within firms. Frans Spinnewyn, Long Term Contracts and Income Redistribution, CORE Discussion Paper 8357 (1985), for example, notes that if workers are risk averse and initially uncertain about how productive they are, they can benefit by agreeing ex ante to have greater cross-sectional wage equality within each work group than would be called for by the variations in productivity that are revealed ex post. ${ }^{102}$ Perhaps, but that seems an unlikely explanation for the wage compression observed in the entries of the Table 4, because for these occupations existing labor contracts cannot prevent the most productive workers from being bid away by rival employers once productivity differences are revealed.

Measurement difficulties might also lead to wage compression, since a firm's wages cannot be expected to track productivity differences that cannot be observed. But this too seems an unlikely explanation for the wage compression observed in Table 4. Individual differences in productivity among sales persons are relatively easy to observe, and the estimate reported for research chemists is based on one component of productivity-long-term contributions to overhead cost recovery from research grants-that can be measured with precision.

${ }^{103}$ R. H. Frank, Are Workers Paid Their Marginal Products?, 74 American Economic Review 549 (1984). 
In the sample studied, the most productive chemists accounted for over $\$ 200,000$ more in revenues each year than their least productive colleagues, yet received only slightly higher salaries. Auto salespersons do not associate nearly as intensively as chemists, but unlike real estate salespersons, they do spend their working hours together in the same location. And as predicted, the price of high-ranked positions for auto salespersons lies between those of the other two occupations.

Table 4. Pay vs. Productivity for Three Occupations.

\begin{tabular}{|c|c|c|}
\hline Occupation & \multicolumn{2}{c|}{$\begin{array}{c}\text { Extra earnings per extra dollar of productivity } \\
\text { Actual }\end{array}$} \\
\hline Predicted by standard model \\
\hline Auto sales & $\$ 0.70$ & $\$ 1$ \\
\hline Research chemists & $\$ 0.24$ & $\$ 1$ \\
\hline
\end{tabular}

Source: Frank, 1984.

4. Calculating the proper multiplier. We propose the following procedure for generating an estimate of the lower bound of the extent to which concerns about local rank contribute to wage compression. (That number will then serve as the basis for our estimate of the extent to which concerns about relative position reduce willingness to pay for safety and other amenities.) We start with the assumption that real estate agents assign no value at all to their income rank vis-à-vis coworkers. This is an exaggeration, to be sure, but perhaps not a serious one in light of the fact that agents spend relatively little time in one another's company. Since real estate agents' earnings grow by 70 cents for every dollar they generate for their employers, our assumption implies that factors other than concern about local rank reduce the slope of the wage-productivity gradient by 0.30 - from 1.0 to $0.70 .{ }^{104}$ In the absence of any adjustment, the entry for research chemists in Table 4 says that the salary of a member of this group will rise by less than 9 cents with every additional dollar of productivity. To simplify, we round up to 10 cents. Applying the 0.30 adjustment, we then estimate that a chemist's salary would rise by 40 cents with every additional dollar of productivity if all factors unrelated to local rank could be controlled for. On this estimate, a university research chemist would be roughly indifferent between the following two events: a) he and his colleagues each receive a $\$ 10,000$ increase in salary; and b) he receives a $\$ 4,000$ increase in salary while his colleagues' salaries remain the same.

The amount a worker is willing to pay for an improvement in local rank within the firm is an understatement of the value of improved relative position more generally, because coworkers are just one of many personal reference groups that matter. Thus, as noted earlier, the income and consumption levels of neighbors, friends, family members, and others are also important components of the overall social frame of reference. Anyone who takes a cut in pay to gain a high ranked position vis-à-vis his coworkers will simultaneously suffer reduced income and consumption rank in those other groups. Accordingly, the amount that workers are willing to sacrifice to hold high-ranked

\footnotetext{
${ }^{104}$ See Spinnewyn, supra, for a discussion of these factors.
} 
positions among their coworkers should be smaller than the value they place on having high relative position more generally.

The extent to which willingness to pay for local rank understates the value of overall relative position will vary inversely with the intensity of coworker interaction. In the extreme case of a firm whose workers were hermetically sealed off from the rest of the world, the observed willingness to pay for high local rank would coincide exactly with the value that workers assign to relative position more generally. In practice, of course, no such firm exists. Among the three cases examined in Table 4, not even the relatively insular world of research chemists would exempt these workers from unfavorable comparisons outside the workplace. To the extent that external comparisons are of at least marginal importance even for members of this group, their observed willingness to pay for local rank will understate their willingness to pay for overall relative position. A research chemist's willingness to pay for local rank (adjusted in the manner described above) is thus a good candidate for use in the construction of a lowerbound estimate of the value of overall relative position. Our estimate, again, is that such a worker would be indifferent between a $\$ 10,000$ across-the-board salary increase and a $\$ 4,000$ increase that applied to him alone.

Our next step is to use this estimate to construct an adjustment in the valuation of safety suggested by conventional methods. Consider again a worker who earns $\$ 50,000$ per year and is shown by hedonic pricing studies to have a reservation price of $\$ 1,000$ per year for a one-in-a-thousand reduction in his annual probability of dying in a workplace accident. Assuming that he and his coworkers spend equal amounts on workplace safety, this payment does not reduce his consumption relative to that of his coworkers, but it produces a $\$ 1,000$ reduction relative to other members of his personal reference group.

For the sake of illustration, we again consider the intermediate case of a worker whose personal reference group consists equally of coworkers and non-coworkers. For this worker, a $\$ 1,000$ expenditure on safety reduces relative income by an average of 1 percent (a zero percent reduction vis-à-vis his coworkers and a 2 percent reduction vis-àvis others). The cost of the additional safety for this worker may thus be expressed as the sum of two components: the $\$ 1,000$ direct expenditure on safety plus the implicit cost of a 1 percent $(\$ 500 / y r)$ reduction in relative income. ${ }^{105}$ What is the latter cost? Our earlier estimate tells us that this worker would be indifferent between a $\$ 1,000$ across-the-board reduction in income and a $\$ 400$ reduction that applied to him alone, implying that he would be also be indifferent between a $\$ 1,250$ across-the-board reduction and a $\$ 500$ reduction that applied to him alone. A $\$ 500$ reduction that applied to him alone, in turn, would impose two costs - a reduction in absolute living standards by that amount and the corresponding reduction in relative living standards. Using $\mathrm{C}_{\mathrm{A}}(500)$ to represent the first cost, and $\mathrm{C}_{\mathrm{R}}(500)$ to represent the second, we have

$$
\mathrm{C}_{\mathrm{A}}(500)+\mathrm{C}_{\mathrm{R}}(500)=\$ 1,250 \text {. }
$$

Since the value of $C_{A}(500)$ is simply $\$ 500$, we solve for $C_{R}(500)=\$ 750$. Under our maintained assumptions, then, the implicit value of a $\$ 500$ reduction in relative income is $\$ 750$. It follows that if this worker were willing to pay $\$ 1,000$ for a one-in-a-thousand

\footnotetext{
105 To simplify, we assume that the cost of a variable decline in relative income vis-à-vis different groups is
} equal to the cost of an equiproportional decline of the same average amount. 
reduction in the probability of death despite the implied 1 percent reduction in his relative standard of living, he would be willing to pay $\$ 750$ more for that same benefit if it could be provided without a reduction in relative living standards. Thus, for cases in which conventional estimates would peg the value of a life at $\$ 5,000,000$ on the basis of observed individual willingness to pay, our estimate would imply a social valuation that is 75 percent larger, or $\$ 8,750,000$ per life.

Needless to say, the back-of-the-envelope nature of this estimate, based on a much less than full inquiry into the contemporary labor market, lays it open to criticism. Considerable work remains to be done before the value of relative position can be estimated with any precision. ${ }^{106}$ Our basic claim is not that we have isolated the precise number, but that even a back-of-the-envelope calculation is likely to be a closer estimate than we would get by simply ignoring concerns about relative position. Even crude estimates like the ones described suggest that ignoring concerns about relative position has led to significant underestimates of the social benefit of reductions in risks to health and safety.

\section{Should Public Policy Address Problems that Stem from Concerns about Relative Position?}

Our argument has been based on a claim about the harmful external effects introduced by the increased income of other people. In our account, increases in the wages of some people impose costs on others. In form, this is a simple externality story, of the sort that has become quite conventional in many areas of law and policy. Economists and noneconomists alike accept the proposition that market allocations may be suboptimal when production is accompanied by the discharge of environmental pollutants, and most concede that air and water quality are proper concerns of public policy. Our suggestion here is that because subjective well-being depends on relative wealth, increases in the income of some people give rise to positional externalities. ${ }^{107}$ Analytically, positional externalities are no different from ordinary environmental pollutants. But although most people accept the existence of positional externalities as a purely descriptive matter, ${ }^{108}$ it might seem tempting to question whether such externalities

\footnotetext{
${ }^{106}$ One complication is that workers might engage in offsetting behavior, designed to ensure a better relative position along the dimension of income even with the regulation. Some might, for example, seek overtime work or a second job. On the general issue of offsetting behavior, see Mathew Adler and Eric Posner, J. Legal Stud. (forthcoming 2000)

${ }^{107}$ R. H. Frank, Positional Externalities, in Richard Zeckhauser, ed., Strategy and Choice: Essays in Honor of Thomas C. Schelling, 25-47 (MIT Press, 1992) .

108 There is indeed an extensive literature in which economists have discussed the dependence of satisfaction on relative living standards. In addition to the authors previously cited, see Arie Kapteyn and F. G. van Herwaarden, Interdependent Welfare Functions and Optimal Income Distribution, 14 Journal of Public Economics 375 (1980); Bernard van Praag, The Relativity of the Welfare Concept, in The Quality of Life, 363, Martha Nussbaum and Amartya Sen, eds., (Clarendon, 1993); Easterlin, 1974; Richard Easterlin, Will Raising the Incomes of All Increase the Happiness of All, 27 Journal of Economic Behavior and Organization, 35 (1995); Amartya Sen, Poor, Relatively Speaking, 35 Oxford Economics Papers 153 (1983); Amartya Sen, The Standard of Living (Cambridge University Press, 1987); Fred Hirsch,. Social Limits to Growth, (Harvard University Press, 1976); Arthur J. Robson, Status, the Distribution of Wealth, Private and Social Attitudes to Risk, 60 Econometrica, 837 (1992); and Tibor Scitovsky, The Joyless Economy (Oxford University Press, 1976).
} 
are a proper basis for policy and law. The principal objections involve, first, freedom and rights and, second, the status of envy.

1. Freedom and rights. On one view, one person's unhappiness about another's increased consumption simply does not constitute a legitimate ground for public action. Smith may be unhappy that Jones consumes more than he does, but the solution is for Smith to mind his own business. On this view, to restrict Jones's consumption because it makes Smith unhappy is essentially no different from telling Jones that he cannot engage in other forms of private conduct to which Smith has some objection, such as reading left-wing magazines, or dating people from another religion, or refusing to floss his teeth. Jones is entitled to engage in such conduct, and that right trumps Smith's concerns.

This objection has obvious rhetorical force; we may agree that the mere fact that conduct is objectionable, or imposes offense, is no ground for legal intervention. Yet the objection elides many difficulties. ${ }^{109}$ People who dislike conduct that they deem objectionable are entitled to bargain with others to prevent them from engaging in that conduct, and when cash payments are not made, implicit accommodations are made all the time, so as to ensure that people do not give one another mutual offense. When bargaining is possible, coercion should certainly be disfavored. But what the argument from "rights" ignores is more fundamental than this -- the possibility that with respect to relative position, people may well find themselves in a position in which they are competing to their collective detriment, and some form of mutual restraint may make all, or almost all, better off. Our claim is about a collective action problem, not about the legitimacy of taxing people whenever they bother, offend, or irritate others.

Consider, for example, the job seeker who gains an advantage over his rivals by showing up for his interview in an expensive, custom-tailored suit. Acting as individuals, the best response for his rivals may be to show up in expensive, custom-tailored suits as well. Even though all job seekers might strongly prefer the alternative in which all spent less on their professional wardrobes, they are stuck with the extra expense. If it were somehow practical for all job seekers to meet and discuss the issue, they might vote unanimously for a proposal to prohibit interviewees from showing up in a suit costing more than, say, $\$ 300$. On what grounds might we then conclude that this proposal is illegitimate? Because it violates the individual job seeker's freedom? That would be a strange objection indeed if each job seeker had just voted in favor of the restriction. If each had wanted to restrict his own freedom in precisely this way, disallowing their

\footnotetext{
109 Among other things, the example shows a problem with the traditional interpretation of John Stuart Mill's idea that government cannot regulate private conduct unless there is "harm to others." See John Stuart Mill, On Liberty. Speaking purely descriptively, a gain to one may impose a "harm" on others, not only because of envy but for other reasons as well. See below. A judgment that this harm cannot count for law and policy may be right, but it must be defended by some kind of claim about the illegitimacy of taking certain harms into account, and not on the basis of the "harm to others" idea alone. It is the question of legitimacy that we discuss in text.

An unhappy implication is that what is standardly seen as a Pareto improvement may not be a Pareto improvement. Consider a two-person society, in which A has 2 and B has 2 (both measuring material payoffs). If a change is instituted by which $\mathrm{A}$ has 20 and $\mathrm{B}$ has 400 (in material payoffs), A might be worse off, because of changes in the social frame of reference, or envy, or harm to self-conception. The problem can be avoided if we see the numbers as reflecting well-being rather than strictly material payoffs. In that case, the material shift just described will, under plausible assumptions, make A worse off, and thus not count as a Pareto improvement at all.
} 
agreement would simply make them worse off - and in an important sense, and even in the most important sense, diminish their freedom as well.

Some might object that such an agreement could never command unanimous support in the first place. Thus there would always be some people whose purpose in wearing custom-tailored suits had nothing to do with wanting to gain advantage over their fellow job seekers. And because the restriction would make such persons worse off, they could hardly be expected to support it. As a practical matter, then, a proposal to limit wardrobe expenses might receive a majority vote, but never a unanimous one.

Yet we do not require unanimity as a precondition for unquestionably legitimate collective action in other spheres. There is no general power of veto on the part of isolated losers. Because most of us value cleaner air, for example, we require motorists to maintain emission-control equipment on their cars, even though some motorists do not care at all about air quality and would be delighted not to have to incur this extra cost. In these and other cases in which important common goals are at stake, we are prepared to restrict what might seem to be individual freedom in the name of the greater good, one of whose components is the perceived freedom of those who seek to emerge from a prisoner's dilemma. ${ }^{110}$

2. Envy? One possible basis for denying the legitimacy of positional concerns is that society has an interest in discouraging negative emotions, above all envy, and that in any case it ought not to reward those who are envious. Perhaps the reason that some are harmed by the income of others is that they are envious; and though envy is a genuine hedonic loss, it might seem wrong to suggest that government has a legitimate interest in taxing those who induce envy in others. To be sure, our argument for reassessing willingness to pay would impose no tax on activities merely because they arouse envy. But the logic of the argument might seem to support that conclusion. ${ }^{11}$

We do not attempt to answer here the complex question whether reducing envy is a legitimate basis for social and legal policy. ${ }^{12}$ On purely utilitarian grounds, it might seem to be, except for the fact that rewarding envy may have unfortunate social effects-by, for example, discouraging production and encouraging further envy, used strategically or otherwise. At the same time, envy might have desirable social effects insofar as it encourages productive activities. ${ }^{113}$ For many people, the question of whether envy should count as a social cost will undoubtedly depend partly on whether it is unfairness that has produced the envy.

What is far more important for current purposes is that we have not been urging attention to relative position on grounds of envy, for even the purely psychological

\footnotetext{
${ }^{110}$ Alternatively, one might object that an agreement limiting what job seekers spend on suits is bound to be unenforceable. After all, if wearing a better suit than others really does help you win the job, there will be powerful incentives to evade the spending limit. One could buy a suit off the rack, for example, and then make under-the-table payments to a tailor who completely re-cut it. This objection might indeed prove decisive. But it concerns the practicality of the proposal, not its political legitimacy.

${ }^{111}$ For a discussion of whether tax policy should respond to positional concerns, see Robert Frank, Luxury Fever, supra.

${ }^{112}$ The point is treated in some detail in John Rawls, A Theory of Justice 530-41 (1971); Rawls urges (to summarize a complex discussion) that rational people do not feel envy when inequalities are not unjust.

${ }^{113}$ The question here is whether people would work too little in the absence of envy; it is possible that envy will induce excessive labor. For a relevant discussion, see Richard McAdams, Relative Preferences, 102 Yale LJ 1 (1992).
} 
consequences of inferior relative position often have nothing to do with envy. Envy entirely to one side, the wealth and consumption of other people sets the frame of reference for our evaluation of our own wealth and consumption, and this effect is impossible to avoid. ${ }^{114}$ The frame of reference is inevitably set socially, not individually, and our experience of social goods - and to some extent our reputation and our selfconception -- will be a function of that frame. In a remote mountain village in India, people can function well without owning an automobile, yet a middle-class citizen in Los Angeles cannot meet even the most minimal demands of social existence without one. This point generalizes to a broad spectrum of goods. When almost everyone has a computer produced in, say, 2005, your computer from 1995 will not only seem hopelessly slow and outdated, its performance will place you at a real competitive disadvantage; but if everyone had computers built in 1995, little or nothing would be amiss. Envy is not involved here; the problem is the frame of reference, which is not within any individual's control. The point holds for people at every level of the economic ladder, except the extremely poor (for whom, it will be recalled, an absolute economic gain is always important, subjectively as well as objectively). Indeed, some of the effects described here appear driven largely by the same neurophysiological mechanisms that explain why a Helsinki resident's evaluation of a 60-degree day in February is more favorable that a Havana resident's evaluation of a 60-degree day in November.

Contextual forces of this general sort influence almost every conceivable dimension of product quality evaluation. Writing more than two centuries ago, for example, Adam Smith introduced the important idea that local consumption standards influence the goods and services that people consider essential (or "necessaries," as Smith called them). In the following passage, for example, he described the factors that influence the amount an individual must spend on clothing in order to be able appear in public "without shame."

By necessaries I understand not only the commodities which are indispensably necessary for the support of life, but whatever the custom of the country renders it indecent for creditable people, even of the lowest order, to be without. A linen shirt, for example, is, strictly speaking, not a necessary of life. The Greeks and Romans lived, I suppose, very comfortably though they had no linen. But in the present times, through the greater part of Europe, a creditable day-labourer would be ashamed to appear in public without a linen shirt, the want of which would be supposed to denote that disgraceful degree of poverty which, it is presumed, nobody can well fall into without extreme bad conduct. Custom, in the same manner, has rendered leather shoes a necessary of life in England. The poorest creditable person of either sex would be ashamed to appear in public without them. ${ }^{115}$

\footnotetext{
${ }^{114}$ It might be said here that those who have a lower frame of reference lack information about possible alternatives. This way of understanding the point is not entirely wrong, but it is imprecise and insufficiently informative; what we mean to emphasize is that the frame of reference is provided socially, not individually, and that any frame of reference will have effects, some of them adverse, on people who must live with it. If most people have cars that are $10 \%$ worse than they might otherwise be, the problem is not that people lack information, but that the relatively less good car produces more satisfaction that it otherwise would.

${ }^{115}$ Adam Smith, Wealth of Nations (Random House, 1937).
} 
The absolute standard of living in the United States today is vastly higher than it was in Adam Smith's $18^{\text {th }}$-century Scotland. Yet Smith's observations apply with equal force to contemporary industrial societies. Consider, for instance, the journalist Dirk Johnson's recent account of the experiences of Wendy Williams, a middle-school student from a low-income family in Dixon, Illinois. ${ }^{116}$

Watching classmates strut past in designer clothes, Wendy Williams sat silently on the yellow school bus, wearing a cheap belt and rummage-sale slacks. One boy stopped and yanked his thumb, demanding her seat.

"Move it, trailer girl," he sneered.

It has never been easy to live on the wrong side of the tracks. But in the economically robust 1990's, with sprawling new houses and three-car garages sprouting like cornstalks on the Midwestern prairie, the sting that comes with scarcity gets rubbed with an extra bit of salt.

To be without money, in so many ways, is to be left out.

"I told this girl: 'That's a really awesome shirt. Where did you get it?'" said Wendy, explaining that she knew it was out of her price range, but that she wanted to join the small talk. "And she looked at me and laughed and said, "Why would you want to know?'"

A lanky, soft-spoken girl with large brown eyes, Wendy pursed her lips to hide a slight overbite that got her the nickname Rabbit, a humiliation she once begged her mother and father to avoid by sending her to an orthodontist.

For struggling parents, keenly aware that adolescents agonize over the social pecking order, the styles of the moment and the face in the mirror, there is no small sense of failure in telling a child that she cannot have what her classmates take for granted.

"Do you know what it's like?" asked Wendy's mother, Veronica Williams, "to have your daughter come home and say, 'Mom, the kids say my clothes are tacky,' and then walk off with her head hanging low."

An adolescent in $18^{\text {th }}$-century Scotland would not have been much embarrassed by having a slight overbite, because not even the wealthiest members of society wore braces on their teeth then. Rising living standards have altered the frame of reference that defines an acceptable standard of cosmetic dentistry. The toll that low relative position takes on individuals is no less legitimate because it occurs in psychological rather than explicitly monetary terms.

To acknowledge that important economic, psychological, and even physical rewards are significantly affected by the spending of others is simply to note an obvious fact of the human condition. Because each individual's consumption affects the frame of reference within which others must make important choices, this frame of reference is no less legitimate an object of public concern than the quality of our air and water.

${ }^{116}$ Dirk Johnson, When Money Is Everything, Except Hers, NY Times A1 (Oct 28, 1998). 
As a purely descriptive matter, concerns about relative position cause current methods to underestimate public willingness to pay for risk reduction and a variety of other benefits by substantial margins. To the extent that we accept citizens' preferences as the basis for policy, we have every reason to believe that correcting for this bias will lead to policy changes that meet public favor.

\section{Limits and Extensions}

In this section we venture some brief remarks on two questions that will eventually deserve extended treatment. The first involves the fact that many regulations involve subclasses of people, rather than (for example) all workers. The second involves the implications of our argument for the much-discussed question of nonwaivable contractual terms.

\section{A. General and Less General Programs}

Thus far we have written as if the effects of the program at issue will be felt by all persons in the relevant class - as if an environmental regulation would reduce all income by the same amount, or as if an occupational safety and health law would reduce workers' earnings at the same time and in the same way. When this is the case, the regulation may produce something close to a Pareto improvement - holding relative position constant with respect to income (and thus imposing little or no loss on that dimension), but offering workers a benefit with respect to a nonpositional good (such as safety or leisure time). Of course things are more complicated than this. Some occupational and safety regulations, for example, will have distinct subclasses of workers - as, for example, when a regulation of coal dust applies largely in the mining industry, but without affecting most other workers at all, ${ }^{117}$ or when a regulation of HIV transmission affects workers in the dental and health care industries, but without applying elsewhere. ${ }^{118}$

When regulation affects subclasses of workers, its positional effects will differ from the ones we described above, where all lose in absolute position, but where relative position is held constant. When subclasses are affected, some will gain in relative position and some will lose. Consider, for example, a safety regulation that applies only to dental workers. In contrast to a regulation that imposed an equally costly safety requirement on all workers -- which, as noted above, does not affect relative living standards -- this more limited regulation will reduce the relative living standards of dental workers. Thus, to the extent that the personal reference groups of dental workers consist largely of non-dental workers, the regulation will make it more difficult for dental workers to match the consumption standards that constitute their social frame of reference.

In such cases, conventional estimates of how much individual dental workers are willing to pay for the regulatory benefit may not significantly understate the social value of the additional safety to dental workers. By hypothesis, the relative income of dental workers is declining. Even in this case, however, the private willingness of dental

\footnotetext{
117 See Occupational Safety and Health Act of 1970, Pub. L. No. 91-596, 84 Stat. 1590, 29 U.S.C. §§ 651678 (1982); W. Kip Viscusi, Fatal Tradeoffs (1991).

${ }^{118}$ See American Dental Ass'n v. Martin, 984 F.2d 823, 824 (7th Cir.), cert. denied, 114 S. Ct. 172 (1993).
} 
workers will understate the social value of the regulation. The reason is that the decline in relative living standards experienced by dental workers is counterbalanced by an increase in relative living standards experienced by others in their social comparison group. Relative position cannot be reduced in the aggregate. When some lose position, others necessarily gain. One upshot is that if dental workers are armed with perfect information, and if they know that their relative and absolute income will decline, a regulation that affects dental workers alone is less likely to be popular among dental workers than one that affects all workers in the relevant social comparison group. Another upshot is that while the more general regulation may produce something close to a Pareto improvement, with few real losers, the more targeted regulation cannot be justified on that ground. If government is nonetheless to use numbers of the sort we are urging, it will be on Kaldor-Hicks grounds - the gainers (including the gainers in terms of relative position) are gaining more than the losers (including the losers in terms of relative position) are losing. In other words, there is a distributional shift, in terms of relative position, with the more targeted regulation, whereas there is no such shift with the general one.

In other cases, a regulation may not alter relative the relative position of those affected by it, even though it applies only to a narrow occupational group. For example, if the relevant social comparison group for coal miners consists largely of other coal miners, a safety regulation that applies only to coal miners would not alter relative position within that group.

In practice, of course, most regulations are likely to fall somewhere along the continuum between these extremes. How, in such cases, is our analysis affected by the fact that regulations target subclasses of people, and not everyone at once? Although the extent to which an individual's private willingness to pay understates the social benefits of a regulation generally will not vary with its breadth of coverage, the popularity of the regulation among those directly affected will tend to be lower the more narrowly the regulation is targeted. Political resistance to safety regulation is thus likely to be greater when regulation is done on a piecemeal basis than when it is proposed as part of a more comprehensive package. In addition, distributional concerns might be raised by piecemeal regulation insofar as it alters existing relative positions. ${ }^{119}$

\section{B. Extensions}

The argument we have made has obvious implications for the question whether law should impose nonwaivable terms - as, for example, through legislation involving maximum hours, job security, parental leave, health care, and leave time. Let us continue to assume that the cost of workers' rights, when they are not waived, will be borne in whole or in part by workers, in the sense that the legal grant of a right, to workers, will result in a lower paycheck. The standard view is that if labor markets are generally competitive, nonwaivable terms cannot be justified as promoting the interests of the supposedly benefited class.

\footnotetext{
${ }^{119}$ We do not believe, however, that this is the most serious of imaginable distributional concerns. In the abstract, there is no reason to think that the losers, in terms of relative position, had any entitlement to their antecedent relative position; and we are not, after all, speaking of redistribution from poor to rich. On distributional concerns and cost-benefit analysis, see various papers in Symposium, J. Legal Stud. (forthcoming 2000).
} 
We submit that the standard view is far too simple. If workers care about relative position, nonwaivable rights might, in principle, make workers better off on the dimension along which they are helped (by giving them something important) while also not making them significantly worse off along the dimension along which they are apparently harmed (by decreasing their income while also decreasing that of everyone else). The promising possibility here is that legal initiatives will produce real gains of one or another kind (for example, leisure time, health care, job security, which are, by hypothesis, nonpositional goods), without producing real losses (because the only loss is to absolute position in terms of income).

To offer slightly more detail: Assume that relative rather than absolute economic position is what most workers care about - that worker well-being would not be decreased by (say) a decrease in annual wages of $\$ 25, \$ 50$, or $\$ 100$, so long as all workers face the same decrease. In that event, some nonwaivable terms, such as a right to job security, might be justified on the ground that the consequence of the new term is to decrease absolute income but to hold relative income constant, thus imposing little or no welfare loss on workers, while at the same time workers receive a substantial benefit, e.g., job security. As far as the worker is concerned, the substantial benefit is given essentially for free, because relative position is held constant - an apparently powerful argument for a wide range of nonwaivable workers' rights.

Of course this argument cannot be shown to be convincing in the abstract. It raises several questions. Perhaps relative position is also what workers carry about with respect to the new, legally granted benefit; perhaps this too is a positional good. Undoubtedly most goods have a mixture of positional and nonpositional features. As we have suggested, it does seem reasonable to say that many of the goods protected by nonwaivable terms -- health care, vacation time, leisure, job security -- have strong nonpositional features; it is important to have these things regardless of what other people have. At least these goods tend to be less observable than income, and also tend to be valued in large part for their absolute qualities. Of course it is important to ask to what extent income is actually a positional good for the relevant class of workers, since, for very poor workers, absolute income may be what matters most.

\section{Conclusion}

Cost-benefit analysis is an increasingly pervasive practice within the national government, and it promises to grow as a tool of decision in the next decades. The first generation debates involved whether to do cost-benefit analysis at all. The second generation debates, now at their inception, involve debates about appropriate valuation.

Our minimal submission here has been that the current numbers for regulatory benefits are too low, because they neglect the fact that people care about relative income position, not only absolute income position. In terms of the very framework used to defend cost-benefit analysis, the current numbers should be increased. More speculatively, we have suggested that the current numbers should be boosted by as much as 75 percent. More conservatively, analysts might use the arguments offered here as a rationale for choosing estimates near the upper end of the range of values produced by contingent valuation and hedonic pricing methods.

We have also suggested that it is entirely legitimate for government to take account of positional externalities, which create a prisoner's dilemma for those subject to 
them. People care about relative position not only and not even mostly because of envy, nor even because of status anxiety, but because the position of others sets a general frame of reference within which economic and social activity takes place. ${ }^{120}$

The point bears not only on cost-benefit analysis, but also on a wide range of regulatory possibilities, including nonwaivable terms in the labor market. If relative position is what matters to most workers, nonwaivable terms, if generally imposed, may turn out to be justified even if the result of such terms is to lower workers' salaries. This suggestion is a natural corollary of our basic suggestion here: Any approach to valuation that concentrates solely on absolute economic position, and neglects relative economic income position, will produce outcomes that are wrong in terms of the conventional arguments that justify cost-benefit analysis in the first place.

${ }^{120}$ For recent evidence, see Truman Bewley, Why Wages Don't Fall During A Recession (2000). 
Readers with comments should address them to:

R obert H . F rank

G oldwin Smith Professor of E conomics, E thics, and Public Policy

Cornell U niversity

Johnson $G$ raduate School of $M$ anagement

327 Sage $\mathrm{H}$ all

Ithaca, NY 14850

C ass R. Sunstein

Karl N . L lewellyn D istinguished Service Professor

University of C hicago L aw School

$1111 \mathrm{E}$ ast 60th Street

Chicago, IL 60637 
Chicago W orking Papers in L aw and E conomics (Second Series)

1. W illiam M. Landes, Copyright Protection of L etters, D iaries and $O$ ther Unpublished W orks: A $n$ E conomic A pproach (J uly 1991).

2. Richard A. E pstein, The Path to The T. J. H ooper: The Theory and $H$ istory of $C$ ustom in the $L$ aw of T ort (A ugust 1991).

3. Cass R. Sunstein, $O \mathrm{n}$ Property and Constitutionalism (September 1991).

4. Richard A. Posner, Blackmail, Privacy, and Freedom of Contract (February 1992).

5. Randal C. Picker, Security Interests, M isbehavior, and Common Pools (F ebruary 1992).

6. Tomas J. Philipson \& Richard A. Posner, O ptimal Regulation of AIDS (A pril 1992).

7. D ouglas G. Baird, Revisiting A uctions in Chapter 11 (A pril 1992).

8. W illiam M. Landes, Sequential versus Unitary Trials: A n E conomic A nalysis (July 1992).

9. W illiam M. Landes \& Richard A. Posner, The Influence of E conomics on L aw: A Q uantitative Study (A ugust 1992).

10. A lan 0 . Sykes, The W elfare $E$ conomics of I mmigration $L$ aw: $A$ Theoretical Survey W ith A $n$ A nalysis of U.S. Policy (September 1992).

11. D ouglas G . B aird, 1992 Katz L ecture: R econstructing C ontracts (N ovember 1992).

12. G ary S. Becker, The Economic W ay of Looking at Life (January 1993).

13. J. M ark Ramseyer, C redibly Committing to Efficiency W ages: Cotton Spinning Cartels in Imperial Japan (M arch 1993).

14. C ass R. Sunstein, E ndogenous Preferences, Environmental L aw (A pril 1993).

15. Richard $A$. Posner, W hat $D$ o Judges and Justices $M$ aximize? (T he Same T hing E veryone E Ise D oes) (A pril 1993).

16. L ucian A rye B ebchuk and Randal C. Picker, Bankruptcy Rules, $M$ anagerial Entrenchment, and Firm-Specific H uman Capital (A ugust 1993). 
17. J. M ark Ramseyer, Explicit R easons for Implicit Contracts: The L egal L ogic to the Japanese M ain B ank System (A ugust 1993).

18. W illiam M . L andes and Richard A. Posner, The E conomics of A nticipatory A djudication (September 1993).

19. Kenneth W. D am, The E conomic Underpinnings of Patent L aw (September 1993).

20. A lan 0 . Sykes, An Introduction to Regression A nalysis (O ctober 1993).

21. Richard A. Epstein, The Ubiquity of the Benefit Principle (M arch 1994).

22. Randal $\mathrm{C}$. Picker, A $\mathrm{n}$ Introduction to $\mathrm{G}$ ame Theory and the L aw (June 1994).

23. W illiam M. Landes, Counterclaims: An E conomic A nalysis (June 1994).

24. J. M ark Ramseyer, The $\mathrm{M}$ arket for $\mathrm{C}$ hildren: Evidence from E arly M odern Japan (A ugust 1994).

25. Robert H . G ertner and G eoffrey P. M iller, Settlement E scrows (A ugust 1994).

26. Kenneth W. Dam, Some E conomic Considerations in the Intellectual Property Protection of Software (A ugust 1994).

27. C ass R. Sunstein, Rules and Rulelessness, (O ctober 1994).

28. D avid Friedman, M ore Justice for L ess M oney: A Step B eyond Cimino (D ecember 1994).

29. Daniel Shaviro, Budget Deficits and the Intergenerational D istribution of Lifetime C onsumption (January 1995).

30. Douglas $G$. Baird, The Law and E conomics of Contract D amages (F ebruary 1995).

31. Daniel Kessler, Thomas M eites, and G eoffrey P. M iller, Explaining Deviations from the Fifty Percent Rule: A M ultimodal A pproach to the Selection of $\mathrm{C}$ ases for Litigation (M arch 1995).

32. G eoffrey P. M iller, D as Kapital: Solvency Regulation of the A merican B usiness E nterprise (A pril 1995).

33. Richard C raswell, Freedom of C ontract (A ugust 1995).

34. J. M ark Ramseyer, Public C hoice (N ovember 1995).

35. Kenneth W. D am, Intellectual Property in an A ge of Software and Biotechnology (N ovember 1995). 
36. C ass R. Sunstein, Social Norms and Social Roles (January 1996).

37. J. M ark Ramseyer and E ric B. Rasmusen, Judicial Independence in Civil L aw R egimes: E conometrics from Japan (January 1996).

38. Richard A. E pstein, T ransaction C osts and Property Rights: O $\mathrm{r}$ D o G ood Fences $M$ ake $G$ ood N eighbors? (M arch 1996).

39. C ass R. Sunstein, The Cost-B enefit State ( $M$ ay 1996).

40. W illiam M . L andes and Richard A. Posner, The E conomics of $L$ egal $D$ isputes $O$ ver the $O$ wnership of W orks of $A$ rt and $O$ ther Collectibles (July 1996).

41. John R. L ott, Jr. and D avid B. M ustard, C rime, D eterrence, and Right- to- $\mathrm{C}$ arry $\mathrm{C}$ oncealed $\mathrm{H}$ andguns (A ugust 1996).

42. C ass R. Sunstein, $\mathrm{H}$ ealth- $\mathrm{H}$ ealth T radeoffs (September 1996).

43. G . Baird, The H idden Virtues of Chapter 11: A n O verview of the $L$ aw and $E$ conomics of Financially D istressed Firms ( $M$ arch 1997).

44. Richard A. Posner, Community, W ealth, and E quality ( $M$ arch 1997).

45. W illiam M . L andes, The Art of $L$ aw and E conomics: $A n$ A utobiographical E ssay (M arch 1997).

46. C ass R. Sunstein, Behavioral A nalysis of L aw (A pril 1997).

47. John R. L ott, Jr. and K ermit D aniel, Term L imits and Electoral Competitiveness: E vidence from California's State L egislative Races (M ay 1997).

48. Randal C. Picker, Simple $G$ ames in a Complex World: A $G$ enerative A pproach to the A doption of N orms (June 1997).

49. Richard A. Epstein, Contracts Small and Contracts Large: Contract $L$ aw through the $L$ ens of $L$ aissez- $F$ aire (A ugust 1997).

50. Cass R. Sunstein, Daniel Kahneman, and David Schkade, A ssessing Punitive $D$ amages (with Notes on Cognition and Valuation in L aw) (D ecember 1997).

51. W illiam M. Landes, Lawrence Lessig, and M ichael $E$. Solimine, Judicial Influence: A Citation A nalysis of Federal C ourts of A ppeals Judges (J anuary 1998).

52. John R. L ott, Jr., A Simple Explanation for W hy Campaign Expenditures are Increasing: The $G$ overnment is $G$ etting Bigger (F ebruary 1998). 
53. Richard A. Posner, Values and C onsequences: A $n$ Introduction to $E$ conomic A nalysis of $L$ aw (M arch 1998).

54. D enise D iPasquale and E dward L. G laeser, Incentives and Social C apital: A re H omeowners B etter Citizens? (A pril 1998).

55. Christine Jolls, C ass R. Sunstein, and Richard Thaler, A Behavioral A pproach to $L$ aw and E conomics (M ay 1998).

56. John R. L ott, J r., D oes a $\mathrm{H}$ elping $\mathrm{H}$ and Put $\mathrm{O}$ thers $\mathrm{At}$ Risk?: A ffirmative Action, Police Departments, and Crime ( $M$ ay 1998).

57. C ass R. Sunstein and E dna U IImann-M argalit, Second-O rder D ecisions (June 1998).

58. Jonathan M. Karpoff and John R. L ott, J r., Punitive D amages: Their D eterminants, E ffects on Firm V alue, and the I mpact of Supreme Court and Congressional A ttempts to Limit A wards (July 1998).

59. Kenneth W. Dam, Self-H elp in the Digital Jungle (A ugust 1998).

60. John R. L ott, Jr., H ow D ramatically Did W omen's Suffrage Change the Size and Scope of G overnment? (September 1998)

61. Kevin A. Kordana and E ric A. Posner, A Positive Theory of Chapter 11 (O ctober 1998)

62. D avid A. W eisbach, Line D rawing, D octrine, and E fficiency in the T ax L aw (N ovember 1998)

63. Jack L. G oldsmith and E ric A. Posner, A T heory of C ustomary International L aw (N ovember 1998)

64. John R. Lott, Jr., Public Schooling, Indoctrination, and T otalitarianism (D ecember 1998)

65. C ass R. Sunstein, Private B roadcasters and the Public Interest: N otes T oward A "T hird W ay" (January 1999)

66. Richard A. Posner, An E conomic A pproach to the $L$ aw of E vidence ( $F$ ebruary 1999)

67. Yannis Bakos, E rik Brynjolfsson, Douglas Lichtman, Shared Information G oods (F ebruary 1999)

68. Kenneth W. Dam, Intellectual Property and the A cademic E nterprise (F ebruary 1999)

69. G ertrud M. Fremling and Richard A. Posner, Status Signaling and the $L$ aw, with Particular A pplication to Sexual $H$ arassment (M arch 1999) 
70. C ass R. Sunstein, M ust Formalism Be D efended E mpirically? (M arch 1999)

71. Jonathan M. Karpoff, John R. L ott, Jr., and G raeme Rankine, Environmental Violations, L egal Penalties, and Reputation Costs (M arch 1999)

72. M atthew D. Adler and E ric A. Posner, Rethinking CostBenefit A nalysis (A pril 1999)

73. John R. Lott, Jr. and W illiam M. L andes, M ultiple Victim Public Shooting, Bombings, and Right-to- $C$ arry Concealed $\mathrm{H}$ andgun Laws: Contrasting Private and Public Law Enforcement (A pril 1999)

74. Lisa Bernstein, The Q uestionable E mpirical Basis of A rticle 2's Incorporation Strategy: A Preliminary Study (M ay 1999)

75. Richard A. E pstein, D econstructing Privacy: and Putting It Back T ogether A gain (M ay 1999)

76. W illiam M . L andes, W inning the A rt L ottery: The E conomic R eturns to the $\mathrm{G}$ anz Collection (M ay 1999)

77. Cass R. Sunstein, D avid Schkade, and D aniel Kahneman, Do People W ant O ptimal D eterrence? (June 1999)

78. Tomas J. Philipson and Richard A. Posner, The L ong-R un $G$ rowth in $O$ besity as a Function of T echnological Change (June 1999)

79. D avid A. W eisbach, I roning $O$ ut the F lat T ax (A ugust 1999)

80. E ric $A$. Posner, $A$ T heory of $C$ ontract $L$ aw under $C$ onditions of Radical Judicial E rror (A ugust 1999)

81. David Schkade, Cass R. Sunstein, and Daniel Kahneman, A re Juries Less Erratic than Individuals? Deliberation, Polarization, and Punitive D amages (September 1999)

82. C ass R. Sunstein, N ondelegation C anons (September 1999)

83. Richard A. Posner, The Theory and Practice of Citations A nalysis, with Special Reference to $L$ aw and Economics (September 1999)

84. Randal C. Picker, Regulating N etwork Industries: A L ook at Intel (O ctober 1999)

85. C ass R. Sunstein, Cognition and Cost-Benefit A nalysis (O ctober 1999) 
86. D ouglas G. Baird and E dward R. M orrison, O ptimal T iming and Legal Decisionmaking: The $C$ ase of the $L$ iquidation D ecision in Bankruptcy (O ctober 1999)

87. G ertrud M . F remling and Richard A. Posner, M arket Signaling of Personal C haracteristics (N ovember 1999)

88. M atthew D. A dler and E ric A. Posner, Implementing C ost$B$ enefit A nalysis W hen Preferences A re D istorted ( $N$ ovember 1999)

89. Richard A. Posner, O rwell versus H uxley: Economics, T echnology, Privacy, and Satire (N ovember 1999)

90. David A. W eisbach, Should the Tax Law Require C urrent Accrual of Interest on Derivative Financial Instruments? (D ecember 1999)

91. C ass R. Sunstein, The L aw of $G$ roup Polarization (D ecember 1999)

92. E ric $A$. Posner, A gency $M$ odels in $L$ aw and $E$ conomics (January 2000)

93. Karen Eggleston, E ric A. Posner, and Richard Zeckhauser, Simplicity and Complexity in Contracts (January 2000)

94. D ouglas G. Baird and Robert K. Rasmussen, Boyd's L egacy and Blackstone's $\mathrm{G}$ host (F ebruary 2000)

95. D avid Schkade, C ass R. Sunstein, Daniel Kahneman, D eliberating about D ollars: The Severity Shift (F ebruary 2000)

96. Richard A. Posner and E ric B. Rasmusen, Creating and E nforcing N orms, with Special R eference to Sanctions ( $M$ arch 2000)

97. D ouglas Lichtman, Property Rights in E merging Platform Technologies (A pril 2000)

98. Cass R. Sunstein and Edna U IImann-M argalit, Solidarity in Consumption (M ay 2000)

99. David A. W eisbach, An Economic A nalysis of Anti-T ax A voidance $L$ aws ( $M$ ay 2000)

100. C ass R. Sunstein, H uman B ehavior and the L aw of W ork (June 2000)

101. W illiam M . Landes and Richard A. Posner, $\mathrm{H}$ armless $\mathrm{E}$ rror (June 2000)

102. Robert H . Frank and C ass R. Sunstein, C ost-B enefit A nalysis and Relative Position (A ugust 2000) 